\title{
A fenntarthatóság mint emberi és társadalmi fejlődés
}

\section{CSATH MAGDOLNA}

Korunk vitatémája a gazdasági növekedés és a fenntarthatóság viszonya. A gazdasági növekedést elsősorban a cégek tevékenységéhez szokták kötni, míg a fenntarthatóságon általában a gazdasági müködés társadalmikörnyezeti hatásait értik. Azonban a fenntarthatóság a társadalom szempontjából ennél tágabban is értelmezhetö. Hiszen meghatározza az emberek fejlödési lehetôségét a gazdaság mindenkori szerkezete, a rendelkezésre álló munkahelyek minösége, de a tanulási és egészségmegörzési lehetöségek is. A cikkben elöször bemutatjuk a fenntarthatóság átfogó értelmezését, fóbb kutatási területeit, majd összefoglaljuk a legismertebb fenntarthatósági kutatások eredményeit és következtetéseit.

Ezután áttérünk a két kevéssé vizsgált részterület, a gazdasági szerkezet és egyes társadalmi jellemzők emberi fejlödésre gyakorolt hatásának részletesebb elemzésére. A magyar adatokat nemzetközi összehasonlitásban vizsgáljuk. Az elemzés alapján bizonyítjuk, hogy a gazdasági fenntarthatóság, azaz a hosszabb távon sikeres gazdasági müködés csak úgy képzelhetö el, ha a gazdasági érdekek még rövid távon sem kerülnek ellentétbe az emberi és társadalmi fenntarthatósággal.

A cikk tehát a kevéssé elemzett emberi és társadalmi fejlödésre mint fenntarthatósági területekre forditja figyelmét, igy a környezeti fenntarthatósággal, amely sokkal szélesebb körben vitatott és elemzett, nem foglalkozik.

Kulcsszavak: fenntarthatóság, gazdasági szerkezet, regionális egyensúly, humán fejlődés, társadalmi harmónia, externáliák

\section{Sustainability as human and social development}

It is a key question of our age how to harmonise economic growth and sustainability. In general economic growth is considered to be related mostly to business activities, while sustainability concerns mostly the effects of economic operations on society and the environment.

However, sustainability is a more complex phenomenon as far as human beings are concerned. The structure of an economy determines the possibilites of human development through the quality of the available jobs. Opportunities for learning and preserving health are also determinants of human development. The article first summarises the main research 
findings of the scholarship on sustainability from a complex perspective. It will also explore the key results and conclusions of the most well-known sustainability reports. Then the paper continues by offering a detailed analysis of two, so far little explored aspects of sustainability, the effects of economic structure and some social characteristics on human development. The Hungarian data will be examined in international comparison. Based on the analysis it will be proved that long term economic success can not be achieved without establishing balance and harmony between even the short term economic interests and human, as well as social sustainability. The article concentrates on the little explored fields of human and social development as research fields of sustainability. Therefore the much more widely analysed and debated environmental sustainability will not be covered

Keywords: sustainability, economic structure, regional equilibrium, human development, social harmony, environmental and social externalities

\section{Bevezetés: a fenntarthatóság értelmezése}

A fenntarthatósági gondolat először az úgynevezett „Brundtland Report”-ban ${ }^{8}$ fogalmazódott meg. A jelentést az ENSZ Környezet és Fejlődés Világbizottsága - amit Brundtland Bizottságnak is neveztek - fogalmazta meg 1987-ben a Közös jövőnk című tanulmányban. Ezt nevezték el később „Brundtland Jelentésnek.” Ez a tanulmány a fenntartható fejlődéssel foglalkozott, amit úgy határozott meg, hogy akkor fenntartható a fejlődés, ha nem veszélyezteti a jelen szükségletek kielégítésével a jövő generációk szükségletének kielégíthetőségét. Azonban a fenntartható fejlődést elképzelhetőnek találták a gyorsuló gazdasági növekedés mellett is feltéve, hogy csökken az anyag- és energiafelhasználás. A tanulmány tehát elsősorban a gazdasági növekedés környezeti hatásait javasolta mérsékelni, de a társadalomra gyakorolt hatásaira inkább csak utalt. A három rendszer, ahogyan az 1. ábrán látjuk, egymás mellettinek tekintette.

A jelentés óta többféle értelmezés is született a fenntarthatósággal kapcsolatban. Az újabb közelítések többsége is a három rendszer, a gazdaság, a környezet és a társadalom összhangjának fontosságáról beszél. Azonban a különböző szerzők más és más területet hangsúlyoznak.

Daly ${ }^{9}$ szerint például a fenntartható fejlődés a folyamatos szociális jólét elérése anélkül, hogy az ökológiai eltartóképességet meghaladó módon növekedne a gazdaság. Roseland is a gazdasági, társadalmi és környezeti rendszerek összhangjának fon-

8 Eredeti címe Our Common Future, amelyet később, Gro Harlem Brundtland korábbi norvég miniszterelnök tiszteletére, Brundtland Jelentésnek neveztek el. PERSÁNYI 1988. 


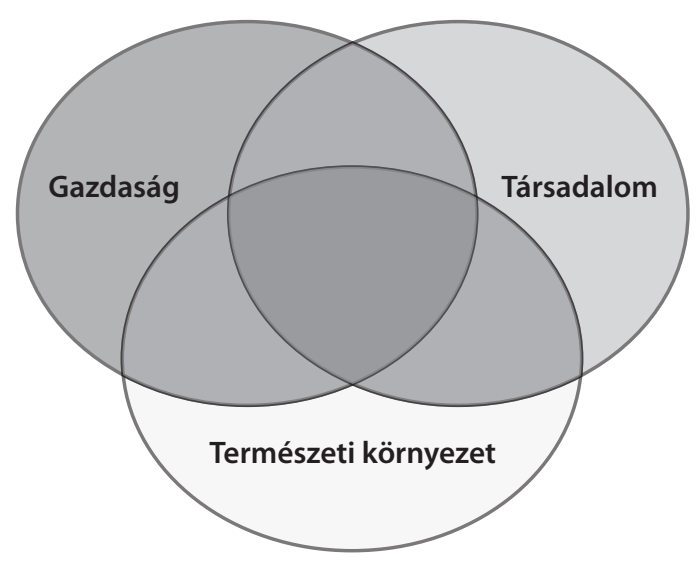

1. ábra: A fenntarthatóság átfedö körei Forrás: Our Common Future 1987

tosságát hangsúlyozza. ${ }^{10} \mathrm{~A}$ helyi, közösségi fenntarthatóság szempontjából egy későbbi művében 6 tőketípust emelt ki: a természeti, fizikai, társadalmi, humán, gazdasági és kulturális tőkét, amelyek összhangjára célszerü törekedni. ${ }^{11}$

Göpel szintén a három rendszer, a gazdaság, társadalom és környezet egymásba ágyazottságát hangsúlyozza úgy, hogy legfontosabbnak a természeti környezetet tartja. ${ }^{12}$ Ezt szemlélteti a 2. ábra.

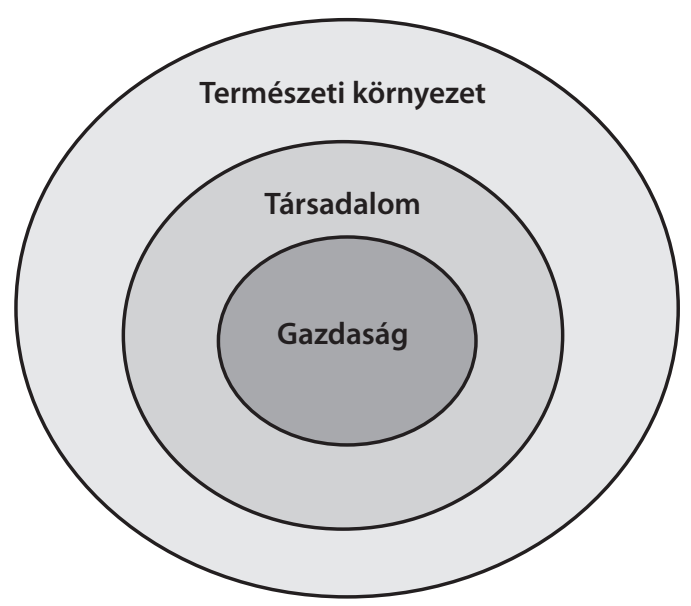

2. ábra: A fenntartható fejlödés elemeinek egymásba ágyazott rendszere Forrás: GÖPEL 2016

10 Roseland 2000.

11 Roseland 2012.

12 GöPEL 2016. 
Gyulai $^{13}$ arra figyelmeztet, hogy sok a félreértés a fenntarthatóság értelmezésében. Így fogalmaz: „Ennek alapvető oka, hogy a fenntarthatóság, a politikai nyelvezet és a köznyelv számára is, valaminek az időben való fennmaradását jelenti. Amikor egy politikus fenntartható gazdasági növekedésről beszél, akkor nem azt érti ezen, hogy ez a növekedés nem növeli a környezeti terheket, hanem azt, hogy a növekedés folytonos." ${ }^{14}$

Ez a szemlélet például az EU fenntarthatósággal foglalkozó stratégiai anyagaiban is visszatükröződik. Például az EU 2020 Stratégia, ${ }^{15}$ amely 2010-ben készült, elsősorban a gazdasági növekedés felől közelíti a fenntarthatóságot, és azt összeköti a versenyképességgel. Úgy fogalmaz, hogy a fenntartható gazdasági növekedés alacsony széndioxid-kibocsátású, versenyképesebb gazdaság létrehozását jelenti, amely hatékonyan és fenntartható módon aknázza ki a természeti erőforrásokat, a környezet védelme érdekében csökkenti a környezeti kibocsátásokat, gondoskodik a biológiai sokféleség megőrzéséről. Mindennek eszközeként új, környezetbarát technológiák és termelési módszerek kifejlesztését javasolja, és ebben véli megtalálni a másokkal szembeni versenyelőnyt.

A fenntarthatóságot - mint látjuk - sok oldalról közelíti a szakirodalom, de többségében azért a három egymással kapcsolatban lévő, egymásra kölcsönösen ható rendszer, a gazdaság, a társadalom és a környezetet fenntarthatóságát érti rajta. Abban azonban már véleménykülönbségek vannak, hogy melyik rendszer fenntarthatóságára kell nagyobb figyelmet fordítani. Többen a társadalmi fenntarthatóságot tartják elsődlegesnek tekintettel arra, hogy - véleményük szerint - a többi rendszerre ennek van a legnagyobb hatása. A társadalmi fenntarthatóságot legegyszerűbben úgy lehet leírni, hogy a társadalom tagjai bíznak egymásban, támogatják egymást és felelősséget éreznek egymás iránt. Továbbá őrzik és erősítik történelmi és kulturális hagyományaikat. Ez a szemlélet a társadalmi harmónia mint emberi fenntarthatóság fontosságát hangsúlyozza. Mérésére általában a társadalmi tőke és az életminőség mutatót szokták használni. A társadalmi fenntarthatóság erősítésének eszközei a civil szervezetek, a társadalmi vállalkozások, a közös kulturális és demokratikus terek, ahol kulturális élményekre lehet együttesen szert tenni, és a közös ügyeket meg lehet beszélni. Fontos eleme a közös jövőkép, a közösen elfogadott értékrend is. Regionális szinten közösségi tőkéről, mint a fenntartható közösségek legfontosabb erőforrásáról is szoktak beszélni. Regionális tekintetben a kutatások különösen a fejlődés regionális kiegyensúlyozottságát mint társadalmi fenntarthatóságot hangsúlyozzák.

Azonban a társadalmi fenntarthatóság vagy, ahogy szintén hívják, a fenntartható társadalom létrehozása, Gyulai szerint, értékrend kérdése is. Így fogalmaz: „A fenntartható társadalom érdekében tehát nemcsak jobb és több technikára, hanem azok bölcs használatára, mértékletességre, igazságosságra, az emberek közötti szeretet

13 Gyulai Iván, írása megjelenésekor az Ökológiai Intézet a Fenntartható Fejlődésért Alapítvány elnöke és az intézet igazgatója.

14 Gyulai 1991, 802.

15 Europa 2020. (COM [2010] 2020.) 
és bizalom újrateremtésére, a környezet értékeinek megbecsülésére és fenntartható használatára van szükség. A fenntarthatóságnak megfelelő társadalmi felépítménynek úgy kell müködnie, hogy az ne gyengítse, hanem megerősítse a fenntarthatósághoz szükséges értékrendet."16

A három rendszer egymással való ütközésének lehetőségét teremtik meg a gazdasági rendszer mérésére alkalmazott $\mathrm{GDP}^{17}$-mutató hiányosságai.

\section{A gazdasági teljesítmény, a gazdasági fenntarthatóság mérésének problémái}

A gazdaság sikeres működése a társadalomnak is érdeke. A Nobel-díjas Samuelson ${ }^{18}$ úgy fogalmazott, nem törődöm vele, hogy ki írja meg egy ország törvényeit, azzal sem, hogy ki szerkeszti meg a szerződéseket, ha én írhatom meg a közgazdasági tankönyveket. Ez a mondás érzékelteti, hogy a gazdaság abszolút elsődlegességének komoly szakmai hívei vannak. Samuelson közgazdaságtan könyve, amely a gazdaság mindenek felettiségét hangsúlyozza a mai napig tankönyv az egyetemeken. A kérdés csupán az, hogy hogyan mérhető a sikeres működés, igaz-e, hogy a siker legjobb jellemzője a GDP-vel mért növekedés?

A GDP a makrogazdaság teljesítményét mérő mutató, de csak azokat a tevékenységeket tudja értékelni, amelyek pénzzel mérhetők. Alapvetően a már legyártott, elkészített termékek, elvégzett szolgáltatások értékét tudja figyelembe venni, ezért múltorientált. A termelés és szolgáltatás környezeti, társadalmi hatásait, az úgynevezett externáliákat nem tudja számításba venni. Úgy is fogalmazhatnánk, hogy a GDP növekedési mutató, és mivel a növekedés nem egyenlő a fejlődéssel, ezért a társadalmi fejlődés, de még a hosszútávú gazdasági fejlődés mérésére sem alkalmas. Ez különösen nagy problémát okozhat akkor, ha a jövővel kapcsolatos mai döntéseket gyorsan változó és nehezen elörejelezhető környezetben a GDP-mutatóra alapozva hozzuk meg. Daly és Cobb így fogalmaz: „Az a gazdasági növekedés, amely ökológiai deficittel jár együtt gazdaságilag is káros, és nem gazdagabbá, hanem szegényebbé tesz bennünket hosszútávon." ${ }^{19}$

Nordhaus és Tobin is már az 1970-es évek elején arra hívta fel a figyelmet, hogy a társadalmi jólét éppen olyan dolgoktól függ a legjobban, amelyeket a GDP nem mér. Ilyen jellemzők például az otthoni tevékenységek, a szomszédokkal való kapcsolatok, vagy általában az egészséges közösségek, az erős társadalmi tőke. ${ }^{20}$

Gyulai arra is figyelmeztet, hogy a társadalmi jólét nem ugyanaz, mint a jóllét. Így ír: „Jóléten az anyagi javak meglétét, jól-léten a jó életet, a méltányos emberi életminőséget értjük. Jól-létünkhöz hozzátartozik az egészséges, biztonságos élet, a barátság,

16 Gyulai 1991, 816.

17 GDP: Gross Domestic Product (bruttó hazai termék).

18 Paul A. Samuelson, amerikai közgazdász. Erre a mondására Weinstein M. M. hivatkozik 2009-ben egy cikkben. (The New York Times, 2009. december 13.)

19 DALY-Совв 1989.

20 Nordhaus-Tobin 1973. 
a szeretet, a hit és a bizalom, a kölcsönös nagylelkűség gyakorlása, a természet adta és társadalom által teremtett lehetőségekhez való egyenlő hozzáférés esélye, a tudás és bölcsesség, a jó környezetminőség, az erkölcsi normák szerinti élet, a munkában való kiteljesedés öröme, az önbecsülés, az identitástudat, az önrendelkezés, a gondoskodás másokról és környezetünkről, az igazságosság, az élet tisztelete."21

Majd levonja a következtetést, hogy nem a jólét termeli a jóllétet, hanem fordítva. Ezzel arra utal, hogy az anyagi jólétre való törekvés szembemehet más értékekkel, ha például feláldozzuk érte a szabadidőnket, az emberi-baráti kapcsolatainkat, sőt néha még az egészségünket is.

A GDP-mutató egyik komoly gyengesége, hogy az otthoni, nyilvánvalóan fontos értéket teremtő munkát képtelen számításba venni. Pedig, ha az édesanya tanítja, ápolja és jól neveli a gyermekét, azzal hosszabb távon sokkal nagyobb társadalmi értéket teremt, mintha elmenne dolgozni egy három műszakos összeszerelö üzembe, és közben sem fizikailag, sem szellemileg nem lenne ereje a gyermekével megfelelően foglalkozni.

De a környezeti fenntarthatóságot is rontja, ha a GDP-vel mért bővülő ipari teljesítmény megnövekedett szállítási igénnyel jár együtt, amely növeli a légszennyezést, ami pedig megbetegíti az embereket.

A GDP további hibája, hogy a káros tevékenységek felszámolásának következményeit eredménynek tünteti fel. Ilyen lehet például az ipari tevékenységek okozta vízszennyezés, amelynek megszüntetésével járó munka éppen úgy növeli a GDP-t, mint maga a szennyező ipari tevékenység. De növeli a GDP-t a társadalmi fenntarthatóságot romboló növekvő bủnözés miatti börtönépítés is, vagy a megnövekedett forgalom okozta zajártalmat csökkentő védőfalak építése. Ezek a tevékenységek valójában nem teremtenek igazi értéket, csak károkat csökkentenek. Viszont beleszámítanak a GDP-be, vagyis a negatív hatások - externáliák - eredményként jelennek meg. Hiszen a növekvő teherautó- és kamionforgalom éppen úgy növeli a GDP-t, mint a megbetegedett ember kezelése, a megnövekedett gyógyszerfogyasztás. A társadalmi fenntarthatósággal azonban nyilvánvalóan ellentétes irányt jelent a GDP ily módon történő növekedése.

Nem alkalmas továbbá a GDP a társadalom szempontjából fontos tudásteremtés közvetlen mérésére sem. Csak a tudásteremtésre fordított ráfordításokat - oktatási kiadások, $\mathrm{K}+\mathrm{F}$ ráfordítások - lehet figyelembe venni a GDP segítségével, illetve bizonyos eredményeket, mint például a létrejött tudást (végzettséget) lehet vele mérni. Azt, hogy a tudásteremtés közvetlenül hogyan hat a gazdasági és társadalmi fenntarthatóságra, már csak közvetett módon, például a létrejövő új innovatív cégek számával, a bejelentett szabadalmakkal, a csúcstechnológiás termékek és szolgáltatások vagy a tudásigényes munkahelyek arányának növekedésével lehet vizsgálni. Ez pedig azért nagy gond, mert a tudásalapú társadalmak esetén a tudásteremtés és -hasznosítás pontos mérése sokkal fontosabb, mint a mennyiségi növekedés bemutatása.

21 Gyulai 1991, 813. 
Nem lehet tehát a GDP-vel mért gazdasági növekedést a társadalmi és emberi fejlődés szempontjából önmagában eredménynek tekinteni. Ezért a gazdasági növekedés fenntartása vagy, ahogy a közbeszédben hallható a „fenntartható növekedés” - amire egyébként a korábban említett EU2020 stratégia is törekszik - csak akkor fogadható el általános célként, ha nincs negatív hatással se rövid-, se hosszútávon a társadalomra, az emberekre és a környezetre.

Ez egyben azt is jelenti, hogy a mennyiségi fenntarthatóság, az állandó növekedésre törekvés helyett a minőségi, szerkezeti változást helyezzük előtérbe. A meglévő szerkezeten belüli mennyiségi növekedés ugyanis bizonyítottan nem fenntartható hosszabb távon. A fenntarthatóság legfontosabb gazdaságszerkezeti kérdése pedig az erőforrásigényes szerkezetről a tudásalapú szerkezetre való áttérés. Ez lehetővé teszi a humán erőforrás hatékonyabb hasznosítását, egyéni fejlődését és ezen keresztül az életminőség általános javulását. A tudásalapú versenyzés azt jelenti, hogy a gazdasági fejlődést az ország a humán vagyonának minőségi jellemzőire: tudására, kreativitására építi. Ez teszi lehetővé egyben azt is, hogy a gazdaság bekapcsolódjék a folyamatos technológiai változásokba, és ne rekedjen meg egy közepes fejlettségi szinten. Ehhez viszont folyamatos tanulásra is szükség van az egész társadalomban. Így lehet egy ország képes arra, hogy - támaszkodva a felkészült lakosságra - tudást teremtsen, és ne legyen gazdaságilag kiszolgáltatva más, tudásteremtésre jobban képes országoknak. A tudásteremtésen kívül fontos a tudás szétáramoltatása is, ami társadalmi együttmüködést, magas bizalmi szintet, társadalmi harmóniát igényel. Ez a folyamat járul hozzá ahhoz is, hogy a lakosság jó munkahelyeken, jó fizetésért és képességeit maximálisan hasznosítva dolgozhasson.

\section{Nemzetközi elemzések a fenntarthatóság területén}

A következőkben összefoglaljuk a legnevesebb fenntarthatósági elemzések meglátásait. Kitűnik az elemzésekből, hogy nincs mögöttük általános elméleti megállapodás a fenntarthatóság mérésének módszereiről, mutatóiról. Általában követik a gazdasági, társadalmi, környezeti fenntarthatóság mint az általános fenntarthatóság elemei modellt. Az alkalmazott mutatók azonban már jelentős mértékben térnek el egymástól.

A legismertebb tanulmány az ENSZ fenntartható fejlődési modellje.

\section{Az ENSZ fenntartható fejlődési céljai}

Az ENSZ fenntartható fejlődési modelljének céljait 2015 szeptemberében 189 ország írta alá azzal, hogy 2030-ra elérik a megfogalmazott 17 fenntartható fejlődési célt. A 189 ország között ott van az EU valamennyi tagországa.
A 17 cél a következő:
- a szegénység felszámolása;
- az éhezés megszüntetése, élelmiszerbiztonság;
- egészséges élet és jóllét; 
- minőségi oktatás, egész életen át tartó tanulás;

- nők egyenjogúságának biztosítása;

- tiszta vízhez való hozzáférés;

- megfizethető, megbízható energiához való hozzáférés;

- tartós, fenntartható gazdasági fejlődés, hatékony foglalkoztatás, tisztességes munka;

- minőségi infrastruktúra, az innováció ösztönzése;

- egyenlőtlenségek csökkentése;

- biztonságos városok, lakóhelyek és közösségek;

- fenntartható fogyasztás;

- klímaváltozás miatti sürgős lépések;

- vizek megőrzése;

- a szárazföldi ökoszisztémák, erdők, talajvédelem, a biológiai sokféleség csökkenésének megállítása;

- békés, befogadó társadalom;

- globális partnerség a fenntartható fejlődés érdekében.

Az ENSZ fenntartható fejlődési céljainak elérését az aláíró nemzetállamok időről időre ellenőrzik, illetve a helyi statisztikai hivatalok is bemutatják, hogy a vizsgált mutatók értéke hogyan alakul. Ez Magyarországon is így történik.

A Nemzeti Fenntartható Fejlődési Tanács ${ }^{22} 2015$ óta minden második évben értékeli Magyarország fenntarthatósági helyzetét elsősorban az országgyülés által 2013 márciusában 2024-ig terjedő időszakra készült Nemzeti Fenntartható Fejlődési Keretstratégia ${ }^{23}$ célkitűzései alapján. De ezen túl vizsgálja az ENSZ 2015. évi fenntartható fejlődési céljaihoz kapcsolódó magyar adatokat is. A legfrissebb értékelés 2019 decemberében történt, amikor is az elért eredményeket kevésnek ítélte meg a szervezet, illetve erős ellentmondást érzékelt a GDP-vel mért gazdasági siker, illetve a humán és társadalmi fenntarthatóság között. Így fogalmazott: Az világjelenség, hogy a tág értelemben vett jólétet meghatározó humán, társadalmi és gazdasági alapok fejlesztése érdekében sok természeti erőforrást áldozunk fel. Az azonban a fejlett országokban ritka, hogy a gazdasági tőke érdekében egy ország elhanyagolja a humán és társadalmi erőforrásai jelentős részének gyarapítását, minőségük javítását. ${ }^{24}$

A jelentés ezért humán fenntarthatósági fordulatot javasol elsősorban a tudástőke bővitése, a népességcsökkenés megállítása és az egészségi állapot javítása érdekében.

22 A Nemzeti Fenntartható Fejlődési Tanács (NFFT) 2008-ban alakult az Országgyűlés kezdeményezésére, annak tanácsadó szerveként.

23 Nemzeti Fenntartható Fejlődési Keretstratégia. Az Országgyűlés 2013. március 25-én fogadta el.

24 Nemzeti Fenntartható Fejlődési Tanács 2019, 4. 


\section{A KSH fenntarthatófejlődés-indikátorai}

A $\mathrm{KSH}^{25}$ fenntarthatósági elemzéseit 4 fö témakör köré csoportosítja. Ezek az:

- emberi erőforrások,

- társadalmi erőforrások,

- természeti erőforrások,

- gazdasági erőforrások.

Legutóbbi kiadványában ${ }^{26}$ rámutat arra, hogy a magyar fenntartható fejlődési keretstratégia, amelynek célja, hogy irányt adjon az egyéni és közösségi cselekvéseknek, szűkebben értelmezi a fenntarthatóságot, mint például az Európai Unió, az ENSZ vagy egyes, a témával részletesen foglalkozó kutatóintézetek. A KSH azonban követi a keretstratégiát, és a vizsgálatait azzal összhangban végzi.

A KSH összesen 103 mutatót elemez, ebből 26 az emberi, 13 a társadalmi, 41 a környezeti és 23 a gazdasági erőforrások állapotát írja le. A vizsgált 103 mutatónál a tendenciák alakulása függvényében egyenként jelzi az adott mutató értékének javulását vagy romlását, vagyis bemutatja az egyes mutatók értékeit és azok változását, de azokat nem hozza egymással összefüggésbe. Így ír erről: „A mutatók többsége a fenntarthatóság csak egy-egy dimenzióját fedi le, így ami a gazdaság szempontjából kedvező változást jelent, az a környezet számára káros lehet."

Ettől függetlenül az elemzések jól használhatók, és különösen azok a mutatók segíthetik a döntéshozókat, amelyek értékét országos szinten, regionálisan, illetve nemzetközi összehasonlításban is bemutatja és elemzi a tanulmány.

Az EU is vizsgálja a nemzetállamok teljesítményét az ENSZ fenntartható fejlődési céljai tükrében. Legutóbb 2019 novemberében jelentetett meg tanulmányt. Ebben a tanulmányban már rangsorok is szerepelnek. Az EU tagállamairól készült 2019. évi fenntartható fejlődési tanulmány ${ }^{27}$ rangsora szerint az ENSZ által kidolgozott 17 fenntartható fejlődési mutató alapján Magyarország a 28 tagország között 2019-ben a 21. helyen van. Csehország a 8., Lengyelország a 16. és Szlovákia a 19.-ik. A listát Dánia, Svédország, Finnország és Ausztria vezeti.

25 KSH: Központi Statisztikai Hivatal.

26 KSH 2019.

272019 Europe Sustainable Development Report 2019. 


\section{Társadalmihaladás-index ${ }^{28}$}

A kutatók a társadalmi haladást 3 mutatócsoporttal mérik. Ezek a következők:

- alapvető emberi szükségletek elérhetősége,

- a jóllét alapjainak rendelkezésre állása,

- lehetőségek a fejlődésre.

A három mutatócsoportot összesen 51 részmutató írja le. Az alapvető emberi szükségletek között például az alap orvosi ellátás, a gyermekhalandóság, a tiszta víz elérhetősége, biztonság, lakásfelszereltség mutatói találhatók.

A jóllét részmutatói a tudás és az információ elérhetőségét, az egészségi állapotot és a környezeti minőséget vizsgálják. Végül, a lehetőségek között - mások mellett - a személyes jogok és választási lehetőségek, a magas szintű tudás elérhetősége, a demokrácia erőssége szerepel.

Fontos, hogy a mutatók között nincsenek gazdasági mutatók. Viszont a kutatók összehasonlítják az egy főre jutó GDP és a társadalmihaladás-index alapján elért pozíciókat azt vizsgálva, hogy mely országok esetén esik a két rangsor messze egymástól. Ha ugyanis nagy a távolság, az azt igazolja, hogy a gazdasági eredmények nem mutatkoznak meg a társadalmi és emberi fejlődésben.

Magyarország a 149 ország között 2019-ben a 39. Csehország a 24., Lengyelország a 33., és Szlovákia a 35. helyen van.

Az alapvető emberi szükségletek alapján a 34., a „jól-lét” mutatók együttese alapján a 43. és az emberi lehetőségek vonatkozásában a 42.-ek vagyunk. A legrosszabb helyezések között a légszennyezés (79), és a korai halálozás (99) szerepel.

Az egy fơre jutó GDP és a társadalmihaladás-pozíció között nagy különbség van például az USA esetén. Az egy főre jutó GDP tekintetében a 8., a társadalmi haladás tekintetében viszont csak a 26. Magyarország az egy főre jutó GDP tekintetében a 38., a társadalmi haladás tekintetében a 39. helyen van. Viszont Csehországra a két érték 30 és 24, vagyis Csehország jobb eredményt ért el 2019-ben a társadalmi haladás, mint a gazdasági növekedés területén. A lengyel adat 36 és 33, a szlovák pedig 33 és 35.

A kutatók arra hívják fel a figyelmet, hogy a gazdasági növekedés és annak társadalmi haladásban megmutatkozó hatásai között nincs mindig szoros összefüggés.

\section{A „felzárkózási index” (Catch Up Index)}

Az indexet az EuPI (European Policies Initiative) ${ }^{29}$ szervezet 35 országra számítja ki négy mutatócsoport alapján, amelyek a következők:

28 Social Progress Index. A „Social Progress Imperative” szervezet kutatásai alapján összeállított átfogó mutató.

29 EuPI European Policies Initiative. www.thecatchupindex.eu/ (2020. 04. 28.) 
- gazdasági mutatók (14 mutató),

- demokráciamutatók (9 mutató),

- életminőség-mutatók (14 mutató),

- kormányzati mutatók (10 mutató).

Valamennyi mutatócsoporton belül találunk fenntarthatósági mutatókat. Közülük a legfontosabbak:

- Gazdasági mutatók:

- adósságszint (a GDP \%-ában),

- a gazdaság energiaintenzitása,

- munkanélküliség.

- Demokráciamutatók:

- bizalmi szint,

- véleménynyilvánítás és elszámoltatás mértéke.

- Életminőség-mutatók:

- Gini-index,

- hosszútávú munkanélküliség,

- szegénységi kockázattal fenyegetettek aránya,

- korai iskolaelhagyók aránya,

- egészségben várható élettartam,

- csecsemőhalandóság,

- emberi fejlődés indexe (HDI),

- felsőfokú végzettségűek aránya.

- Kormányzati mutatók:

- korrupcióérzékelési index,

- öngyilkosságok aránya (100 ezer főre vetítve),

- e-kormányzás elterjedtsége.

A felzárkózási index kiszámításához statisztikai adatokat és felméréseket használnak. A felmérések alapján számított adatok esetén felmerülhetnek módszertani problémák a tekintetben, hogy elegendő számú volt-e a minta és megfelelő volt-e a különböző szempontok szerinti reprezentáltság. Ennek tudatában érdemes elemezni az általános helyezéseket.

2018-ban az összes mutató alapján készített rangsort azEU-ban Dánia és Svédország vezeti. Csehország a 13., Szlovákia a 21., Lengyelország a 22., Magyarország a 24.

A felzárkózási index kapcsán elsősorban a társadalmi fenntarthatóság szempontjából fontos életminőség és kormányzati mutatók szerinti helyezéseket érdemes megvizsgálni. Az életminőség mutatócsoport esetén Finnország és Hollandia van az élen. Csehország a 14., Lengyelország a 20., Szlovákia a 21. és Magyarország a 25. A kormányzati mutatók alapján Finnország és Svédország vezet, Csehország a 13., Szlovákia a 20., Lengyelország a 22., Magyarország a 23. 


\section{A befogadó növekedési és fejlődési index ${ }^{30}$}

A növekedési gondolkodás ellensúlyozására, a fenntarthatósági szempont figyelembevételére dolgozták ki az úgynevezett befogadó növekedési és fejlődési indexet, amelyet 30 fejlett, 63 közepes és 16 alacsony jövedelmü, összesen 109 országra számítanak ki.

Ebből kifolyólag csak országcsoportokon belüli összehasonlításra van lehetőség. Csehország és Szlovákia például már a fejlett gazdaságú országok csoportjában található, míg Magyarország és Lengyelország a „felső közepes” jövedelmű országok között van.

Az index számítását a következőképpen indokolja a WEF: az index azért fontos, mert sokkal átfogóbb és árnyaltabb képet ad a fejlettségről, mint a GDP. Hiszen végső soron a gazdasági növekedés célja is sokkal inkább az életminőség javítása, mint pusztán a termékek és szolgáltatások növekvő mértékủ előállítása kell hogy legyen.

Ezért a kutatás alapján V4-es összehasonlítás nem végezhető el.

A tanulmány három mutatócsoportot elemez, amelyek a következők:

- növekedés és fejlődés,

- befogadottság,

- generációk közötti egyenlőség és fenntarthatóság.

A három mutatócsoport mindegyike négy részmutatót tartalmaz a következők szerint:

- növekedés és fejlődés:

- GDP/fö,

- termelékenység,

- foglalkoztatottság,

- egészségben várható élettartam;

- befogadottság:

- medián háztartási jövedelem,

- GINI-index a jövedelmekre,

- GINI-index a vagyonra,

- szegénységi ráta;

- generációk között egyenlőség és fenntarthatóság:

- nettó megtakarítás,

- államadósság a GDP \%-ában,

- a GDP karbonintenzitása,

- függőségi arány (a nyugdíjasok és a 15 éven aluliak aránya a munkaképes korosztály százalékában).

30 Inclusive Growth and Development Index. Az indexet a World Economic Forum (WEF) számítja ki. Az adatok a 2017. évi elemzésből származnak. www.weforum.org/reports/the-inclusive-growthand-development-report-2017 (2020. 04. 28.) 
Érdekes ellentmondásra jutnak az elemzők. Az átfogó index alapján ugyanis össze lehet hasonlítani a csupán GDP-növekedésen alapuló rangsort a fenntarthatósági szempontokat is figyelembe vevő mutatók alapján kapott rangsorral. Ennek megfelelően a vizsgált országokat három csoportba osztják:

- a GDP-növekedési pozícióhoz képest alacsonyabb fenntarthatósági pozíció,

- a GDP-növekedési pozícióhoz képest magasabb fenntarthatósági pozíció,

- közel egyező pozíció a növekedésre és fenntarthatóságra.

A harmadik csoportban az EU legfejlettebb országait, Németországot, Svédországot, Ausztriát, Dániát, az EU-n kívüli országok közül pedig Norvégiát és Svájcot találjuk. A második csoportban van például régiónkból Csehország és Szlovákia. Az elsőben pedig itt is az USA helyzete a legmeglepőbb: ugyanis miközben a vizsgált országok között az egy före jutó GDP tekintetében a 9., a fenntarthatósági index alapján csak a 23.

A WEF-elemzés fő gyengesége, hogy túl sok mutatót vizsgál, és azokat nem csoportosítja egyértelműen fenntarthatósági területenként. Továbbá az egy főre jutó GDP alapján képzett országcsoportok nem teszik lehetővé egy általános rangsor készítését. Ez azért is ellentmondásos, hiszen a bevezetőben éppen azt hangsúlyozza a tanulmány, hogy a GDP-n túli átfogóbb, árnyaltabb kép nyújtása a célja. Végső soron azonban a tanulmány a gazdasági növekedés fontossága mellett áll ki, csak azt javasolja, hogy az legyen „befogadóbb”, azaz eredményeit a társadalom, az emberek többsége is érzékelhesse.

\section{Humántőke-elemzések}

Az átfogóbb fenntarthatósági elemzések mellett vannak olyanok is, amelyek a fenntarthatóság emberi vonatkozását vizsgálják. Ezek célja általában az, hogy az emberek jóllétének, fejlődésének eredményeit mint a gazdasági, versenyképességi pozíciók javíthatóságának feltételeit mutassák be, ugyanis a humán tőke minősége a gazdasági fenntarthatóságnak is kiemelkedő fontosságú eleme. A minőséget pedig a képességek, tudás, egészségi állapot - fizikai, mentális és érzelmi - együttesen határozza meg. Éppen ezért - állítják az elemzések - az államnak feladata a humán tőke minőségének nemcsak megtartása, hanem folyamatos javítása is. Ezzel a szemlélettel vizsgálják a különböző kutatások a humán tőke minőségét, továbbá azt, hogy az egyes kormányok mennyire fektetnek be a humán tőkébe.

Az alkalmazott mutatók száma és típusa sokféle. A humántőke-állapotot egyes kutatók az emberek teljes élettartama mentén, mások pedig adott időpontban, statikusan vizsgálják. 


\section{Az ENSZ HDI ${ }^{31}$-elemzése}

Az egyik jól ismert és szakmailag elismert humántőke-elemzést az ENSZ egyik szervezete, a UNDP ${ }^{32}$ készíti, amelynek alapján hosszú ideje, körülbelül 30 éve, minden évben megjelenteti az úgynevezett HDI-indexet. A kutatás mottója: „, a nemzetek igazi vagyona az ember". Az index 4 mutató alapján rangsorolja a vizsgált országokat. Ezek:

- a születéskor várható élettartam (egészségi állapot),

- a várhatóan tanulással töltött évek száma (tanulás, tudásszerzés),

- az átlagos iskolai végzettség (képzettség),

- a bruttó nemzeti jövedelem egy főre jutó értéke (vásárlóerő-paritás ${ }^{33}$ ) (életszínvonal).

A HDI-index alapján - a vizsgált 189 ország között - a rangsor élén 2019-ben Norvégia, Svájc, Írország és Németország található. A V4-országok és Ausztria helyezése összehasonlítva a 2015. évi pozícióval a következő:

1. táblázat: HDI-index alapján az országok pozíciója

\begin{tabular}{lcc}
\hline \multicolumn{1}{c}{ Ország } & 2015 & 2019 \\
\hline Magyarország & 44 & 43 \\
Csehország & 28 & 26 \\
Lengyelország & 36 & 32 \\
Szlovákia & 35 & 36 \\
Ausztria & 23 & 20 \\
\hline
\end{tabular}

Forrás: Human Development Report 2015, 2019

\section{INSEAD-, ADECCO-, TATA-elemzések}

A humán vagyont mint a versenyképesség, a fenntartható fejlődés legfontosabb feltételét elemzi évente az INSEAD, ADECCO Group, TATA cégek kutatógárdája. ${ }^{34}$ Az elemzéseket 20 mutatócsoport segítségével végzik. Ezek egy része a képzési rendszereket tartalmazza, beleértve az „élet végéig tartó” tanulási lehetőséget is. De vizsgálják a környezet jellemzőit és az életminőséget is.

A kutatók 125 ország adatait hasonlítják össze. A listán Csehország a 25., Szlovákia a 41., Lengyelország a 42. és Magyarország az 53. A legrosszabb helyezésünk ebben a kutatásban is a vonzó emberi környezettel, az életminőséggel kapcsolatos (78. hely),

31 HDI: Human Development Index (emberi fejlődés indexe).

32 „ENSZ Fejlődési Program” (United Nations Development Programme, rövidítve UNDP).

33 A vásárlóerőparitás-mérés kiküszöböli az árak különbözősége miatti torzító hatásokat.

34 LanVin-Monteiro 2019. 
de rossz a pozíciónk a képzési rendszerek hatékonyságára is (83.), amelynek fő oka a felnőttképzésben, azaz az „élet végéig tartó tanulásban”, és a cégeken belüli képzésben érzékelhető gyenge eredményeinkre vezethető vissza. Ezeken a területeken a 108., illetve a 97. helyen vagyunk. De - nemzetközi összehasonlításban - keveset fordítunk felsőoktatásra is. A 73. helyre kerültünk.

\section{Az IMD tehetségindexe}

Az IMD Svájci Versenyképességkutató a humán tőkét inkább a versenyképességgel, mint gazdasági fenntarthatósággal összefüggésben vizsgálja. A 2019. évi tanulmányában ${ }^{35}$ azt hangsúlyozza, hogy a fenntartható gazdasági fejlődés kulcsa a felkészült és folyamatosan tanuló, a jövőre felkészülő lakosság, és az az állami politika, amely ezt a fejlődést oktatási befektetésekkel támogatja. 63 ország adatait hasonlítják össze 3 mutatócsoport segítségével, amelyek további részmutatókat foglalnak magukban. A három mutatócsoport:

- humán tőkébe való beruházás,

- vonzó környezet, a szakemberek megtartása,

- a jövőre való felkészültség.

Az összes vizsgált mutatók száma 32. A 63 országot tartalmazó listát Svájc, Dánia, Svédország és Ausztria vezeti. Lengyelország a 37., Csehország a 39., Magyarország a 45. és Szlovákia az 57. helyen van. A V4-országok és Ausztria részterületenkénti és általános helyezését a 2 . táblázatban látjuk.

2. táblázat: A humántőke-mutatócsoportok szerinti helyezések

\begin{tabular}{lcccc}
\hline \multicolumn{1}{c}{ Ország } & $\begin{array}{c}\text { Tudásba való } \\
\text { befektetés }\end{array}$ & $\begin{array}{c}\text { Vonzó } \\
\text { környezet }\end{array}$ & $\begin{array}{c}\text { Jövőre való } \\
\text { felkészültség }\end{array}$ & $\begin{array}{c}\text { Általános } \\
\text { helyezés }\end{array}$ \\
\hline Magyarország & $\mathbf{3 3}$ & $\mathbf{5 6}$ & $\mathbf{5 7}$ & $\mathbf{4 5}$ \\
Csehország & 40 & 45 & 39 & 39 \\
Lengyelország & 27 & 46 & 45 & 37 \\
Szlovákia & 47 & 54 & 59 & 57 \\
Ausztria & 4 & 13 & 10 & 4 \\
\hline
\end{tabular}

Forrás: IMD 2019

Magyarország esetén érdemes felfigyelni arra, hogy a tudásbefektetés, oktatás, képzés területén nem állunk rosszul a vizsgált országok között. Megelőzzük Csehországot és Szlovákiát is. Például az oktatásra fordított GDP-arányos kiadások tekintetében jó a pozíciónk, a 63 ország között a 22.-ek vagyunk. Viszont a vonzó környezet, a jó szakemberek megtartása területén a mi pozíciónk a legrosszabb. A vonzó környezet,

$35 \quad$ IMD 2019. 
a tudásmegtartás mutatócsoporton belüli részmutatók esetén az egészségmegőrzést támogató egészségügyi infrastruktúra és az általános életminőség részmutatókra különösen gyenge a helyezésünk (56. és 54. pozíció).

Ezt összefüggésbe hozzák a kutatók a jó szakemberek elvándorlásával, ami - a gazdasági fenntarthatóság mellett - a humán-társadalmi fenntarthatóságot is rontja.

\section{A Világbank humántőke-indexe}

A Világbank humántőke-indexe ${ }^{36}$ mennyiségi és minőségi jellemzőket is vizsgál. Többek között méri a születéstől az iskolás korig tartó életben maradás és a minőségi iskolázottsághoz jutás esélyeit, az egészségmegőrzés lehetőségeit és a felnőttként várható élettartamot.

A kutatók bizonyítják, hogy a magasabb humántőke-indexű országok gazdasági teljesítménye is jobb. Ennek egyik oka, hogy a magasan képzett és egészséges munkavállaló jobb minőségủ és magasabb termelékenységủ munkát tud végezni.

Az összehasonlított 157 ország listáján régiónk jó pozícióban van: Csehország a 24., Lengyelország a 30., Magyarország a 38. és Szlovákia a 40. helyen van. A fejlett EU-s gazdaságok között a legjobb helyen Finnország (5.), Írország (6.), Svédország (8.) és Hollandia (9.) található. A lista első 4 helyén ázsiai országok vannak. A listán élenjáró országok a versenyképességi rangsorokban is jó helyezést érnek el, ami igazolja, hogy a humán vagyon a gazdasági-társadalmi fejlődés és a versenyképesség egyik legfontosabb forrása.

\section{Az Európai Bizottság humántőke-előrejelzése}

Lutz és szerzőtársai ${ }^{37} 201$ országra kiterjedő elemzésében más szempontok szerint vizsgálják a humán tőkét. Ez a tanulmány arra is figyelmeztet, hogy a nemzetállamokból való tartós szakember-elvándorlás jelentősen gyengíti a nemzeti humán vagyont, azaz a humán fenntarthatóságot. De rontja a társadalmi harmóniát is, hiszen családokat szakít szét. Ezt a problémát elsősorban a kelet-európai országok esetén tartja veszélyesnek. Ezen túl szintén a képzettség-tudás szintet, az annak javítását lehetővé tevő oktatási befektetéseket tartja fontosnak. De hangsúlyozza az egészséges korszerkezetet, a fiatalkorúak megfelelő arányát is mint fontos fenntarthatósági szempontokat.

A részletes országelemzésben Magyarország esetén drámai humánvagyon-vesztést jelez előre: 2060-ra 8 millió före való lakosságcsökkenést. Az átlagos életkor ekkorra 50,3 évre nőne és a fiatalkorúak (0-14 éves korcsoport) aránya az idősebb korosztályhoz (15-64 éves korcsoport) mérve csupán 0,23 fő lenne. A várható élettar-

36 The World Bank Group 2018.

37 Lutz et al. 2018. 
tamot férfiak esetén 80,6, nők esetén 87,6 évre becsüli. Ezek az előrejelzések a humántársadalmi fenntarthatóság szempontjából nagyon kedvezőtlenek. Nézzük meg őket V4-es és Ausztriával történő összehasonlításban is.

3. táblázat: Humántőke-adatok 2015-ben és elörejelzés 2060-ra. V4-ek és Ausztria

\begin{tabular}{|c|c|c|c|c|c|c|c|c|}
\hline \multirow[t]{3}{*}{ Ország } & \multicolumn{2}{|c|}{$\begin{array}{l}\text { Lakosság } \\
\text { száma }\end{array}$} & \multicolumn{2}{|c|}{$\begin{array}{l}\text { Medián } \\
\text { életkor }\end{array}$} & \multicolumn{2}{|c|}{$\begin{array}{c}\text { Fiatalok aránya } \\
\text { az idősebb } \\
\text { korosztályhoz } \\
\text { mérve }\end{array}$} & \multicolumn{2}{|c|}{$\begin{array}{c}\text { Várható } \\
\text { élettartam } \\
2060\end{array}$} \\
\hline & 2015 & 2060 & 2015 & 2060 & 2015 & 2060 & Férfiak & Nők \\
\hline & \multicolumn{2}{|c|}{ millió } & \multicolumn{2}{|c|}{ év } & \multicolumn{2}{|c|}{$\%$} & \multicolumn{2}{|c|}{ év } \\
\hline Magyarország & 9,78 & 8,0 & 41,7 & 50,3 & 0,21 & 0,23 & 80,6 & 87,6 \\
\hline Csehország & 10,6 & 9,65 & 41,4 & 50,0 & 0,23 & 0,26 & 84,5 & 90,2 \\
\hline Lengyelország & 38,27 & 31,82 & 39,7 & 51,5 & 0,21 & 0,26 & 82,6 & 89,7 \\
\hline Szlovákia & 5,44 & 4,69 & 39,2 & 50,3 & 0,22 & 0,26 & 82,4 & 88,8 \\
\hline Ausztria & 8,68 & 9,39 & 43,2 & 50,3 & 0,21 & 0,24 & 88,1 & 92,7 \\
\hline
\end{tabular}

Forrás: LuTz et al. 2018

Az EU-tanulmány nem készít országsorrendet. Csak egyedileg elemzi az országok humán tőkéjének alakulását. Előrejelzése azonban fontos humán fenntarthatósági problémára hívja fel a figyelmet.

A bemutatott rangsorok és elemzések különböző fenntarthatósági szempontok szerint vizsgálták a kiválasztott országokat. Egyrészről arra mutattak rá, hogy a fenntarthatóság szerteágazó témakör, ezért eredményességét nehéz néhány mutatóval mérni, sőt magát a fenntarthatóságot is nehéz definiálni. Másrészről pedig - talán a HDI-mutató kivételével - az elemzések a gazdasági növekedés fenntarthatóságából kiindulva elemezték a humán és társadalmi tényezőket. A rangsorokat azonban mégis érdemes összefoglalóan is áttekinteni. A 4. táblázatban a V4-országok 7 rangsorban elfoglalt helyét látjuk.

Az összegző táblázat szerint az elemzések többségében - 6 esetben - Csehország van a legjobb pozícióban. Ez egyben magyarázza azt is, hogy Csehország miért elözi meg a versenyképességi és innovációs listákon is a többi 3 országot. Kiemelendő, hogy Csehországban - ezek szerint - a gazdasági eredmények jobban összhangban vannak az emberi és humán fejlődési eredményekkel, mint a többi országban. Erre egyébként azok a korábban bemutatott vizsgálatok is utaltak, amelyek a GDP-adatok szerinti sorrendet a humán fenntarthatósági sorrenddel hasonlították össze. Ezekre az összefüggésekre - fontosságuk miatt - a továbbiakban még visszatérünk. Most térjünk át kiemelt témánk, az emberi és társadalmi fenntarthatóság részletesebb vizsgálatára. 
4. táblázat: A magyar helyezések az egyes mutatók mentén a V4-es országok között a különbözö nemzetközi elemzések alapján

\begin{tabular}{|c|c|c|c|c|c|}
\hline \multirow{2}{*}{ Mutatók } & Csehország & $\begin{array}{c}\text { Magyar- } \\
\text { ország }\end{array}$ & $\begin{array}{l}\text { Lengyel- } \\
\text { ország }\end{array}$ & Szlovákia & Ausztria \\
\hline & \multicolumn{5}{|c|}{ pozíciók } \\
\hline EU 2019. évi indexe & 8 & 21 & 16 & 19 & 28 \\
\hline $\begin{array}{l}\text { Társadalmi- } \\
\text { haladás-indexe }\end{array}$ & 24 & 39 & 33 & 35 & 149 \\
\hline Felzárkózási index & 13 & 24 & 22 & 21 & 35 \\
\hline $\begin{array}{l}\text { UNKDP - } \\
\text { HDI-index }\end{array}$ & 26 & 43 & 32 & 36 & 189 \\
\hline $\begin{array}{l}\text { INSEAD - } \\
\text { ADECCO -TATA }\end{array}$ & 25 & 53 & 42 & 41 & 125 \\
\hline IMD-tehetségindex & 39 & 45 & 37 & 57 & 63 \\
\hline $\begin{array}{l}\text { Világbank humán } \\
\text { index }\end{array}$ & 24 & 38 & 30 & 40 & 157 \\
\hline Első hely & 6 & - & 1 & - & - \\
\hline Utolsó hely & - & 5 & - & 2 & - \\
\hline
\end{tabular}

Forrás: a szerző számítása

\section{A gazdasági szerkezet mint az emberi fejlődés lehetősége}

Maslow $^{38}$ az 1950-es években dolgozta ki elméletét azzal kapcsolatban, hogy az embereket mi motiválja teljesítményre. Az ötszintü hierarchiamodelljében a legfelső szinten az az igény van, hogy az ember folyamatosan fejlődhessen, kiteljesíthesse képességeit, alkothasson. Ehhez azonban gazdasági, emberi és társadalmi lehetőségekre egyaránt szükség van. Ha pedig az emberek kiteljesíthetik képességeiket, az nemcsak nekik, hanem a gazdaságnak és a társadalomnak is hasznos, és szolgálja a fenntartható fejlődés mindhárom alrendszerét.

A következőkben, nemzetközi összehasonlításban a gazdasági szerkezetet mint az emberi és társadalmi adottságok kínálta emberi fejlődési lehetőséget vesszük górcső alá néhány fontos mutató segítségével. Ugyanis a gazdaság szerkezete meghatározza azt, hogy milyen minőségű, mekkora tudást igénylő munkahelyek állnak rendelkezésre egy gazdaságban.

Ha a jól felkészült emberek nem találnak megfelelő munkahelyet, és ezért képességeik alatti szinten kénytelenek dolgozni, akkor alulfoglalkoztatottságról beszélünk, ami a humán vagyon pocsékolása. Gyakran éppen az ilyen helyzetek indítják be az elvándorlást, az úgynevezett agyelszívást. A gazdasági szerkezetet jellemzi a munkahelyek minősége, és a tudást, kreativitást igénylő munkahelyeket kínáló, innovatív cégek aránya. Fontos és kapcsolódó mutató az is, hogy a cégek mennyit költenek kutatás-fejlesztésre

38 Abraham Maslow amerikai pszichológus (1908-1970). MAsLow 1943. 
és hány embert foglalkoztatnak kutató-fejlesztő munkahelyeken nemzetközi összehasonlításban. A 3. ábra ezeket az adatokat szemlélteti nemzetközi összehasonlításban.

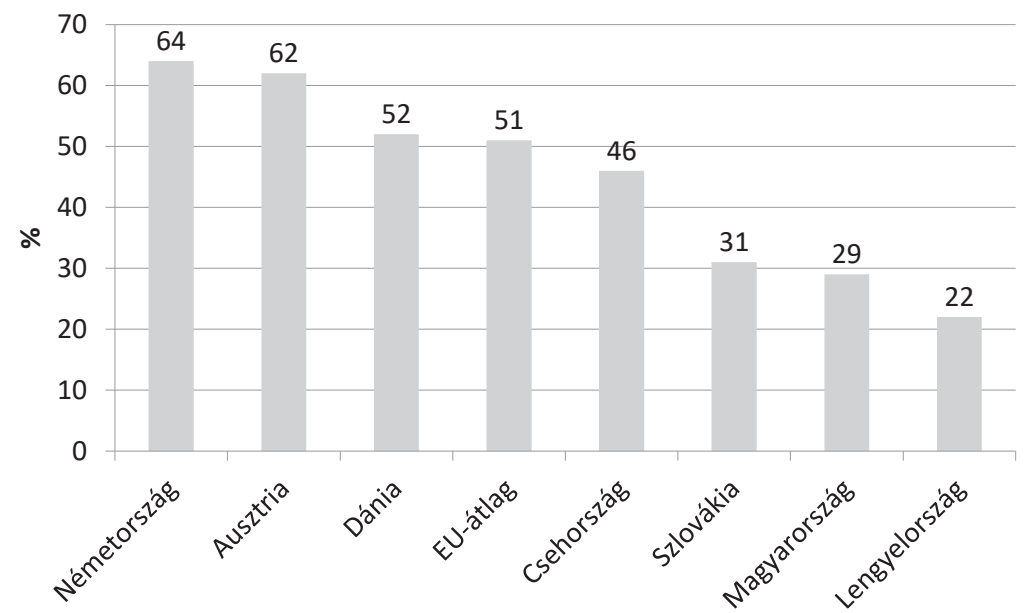

3. ábra: Az innovatív cégek aránya a V4-országokban, Ausztriában, Németországban, Dániában és az EU-ban átlagosan (2016, \%)

Forrás: a szerzö szerkesztése az Eurostat adatainak alapján

A 3. ábra alapján, Magyarországon, Lengyelország után a második legkisebb esélye van egy munkavállalónak arra, hogy innovatív, tudásalapú cégnél dolgozhasson. Ez csökkentheti annak lehetőségét, hogy a munkavállalók tudásban fejlődhessenek, hiszen nem tart esetleg igényt innovatív, kreatív képességeikre foglalkoztatójuk. A 4. ábra azt szemlélteti, hogy a cégek mennyit költöttek kutatás-fejlesztésre 2018-ban, és ez hány \%-a volt a GDP-nek.

A 4. ábra adatai összhangban vannak a 3. ábráéval. Ha ugyanis kevés az innovatív cég, akkor nyilván a $\mathrm{K}+\mathrm{F}$ ráfordítás is alacsony. Fel kell figyelni azonban a jelentős különbségekre a V4-ek és a fejlett országok adatai között. Németországban a cégek több mint hatszorosát költik kutatás-fejlesztésre, mint a Magyarországon működő cégek. Érdemes külön megnézni, hogy milyen a kutatás-fejlesztési tevékenysége az összes magyar hozzáadott értékhez több mint 50\%-kal hozzájáruló külföldi tulajdonú cégeknek. Az 5. ábra a cégek által megtermelt hozzáadott - új érték - százalékában mutatja meg a K + F-re fordított értéket, illetve az összes foglalkoztatotthoz mérve a kutatásfejlesztésben foglalkoztatottak arányát néhány országban a feldolgozóiparban. Azért a feldolgozóipart érdemes elemezni, mert ebben az ágazatban jellemző a külföldi cégek magas aránya. 


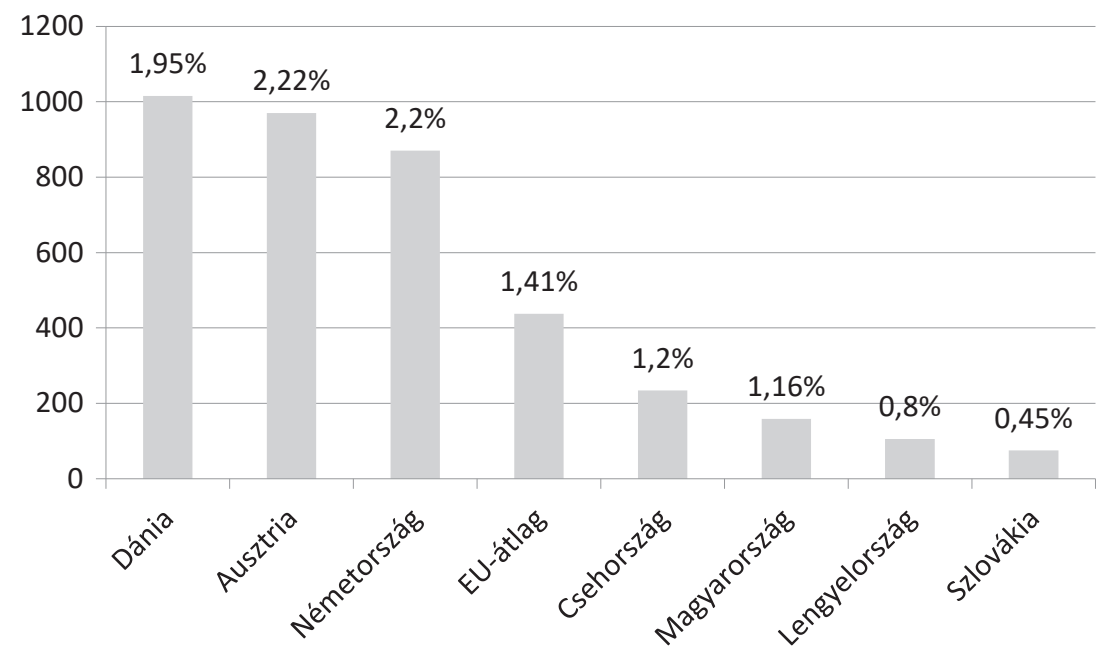

4. ábra: $K+F$ ráfordítások a gazdaságban a V4-országokban, Ausztriában, Németországban, Dániában és az EU-ban átlagosan, 2018 (euro/fó)

Forrás: a szerző szerkesztése az Eurostat adatainak alapján

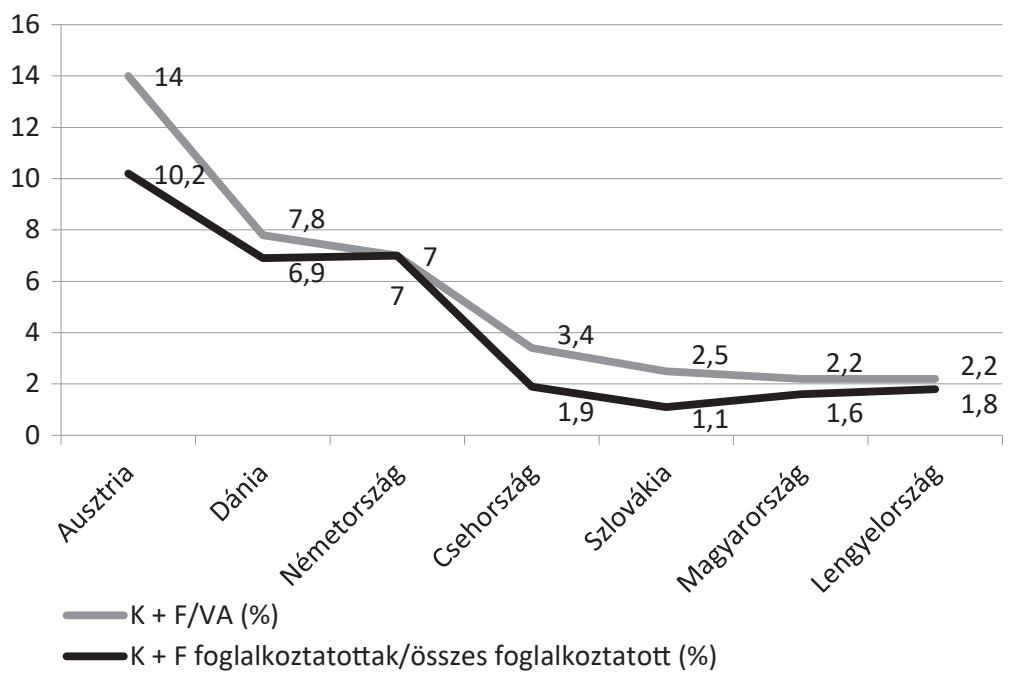

5. ábra: A külföldi tulajdonú cégekben $K+F$-re forditott összegek aránya a megtermelt új értékben (VA) és a $K+F$ területen foglalkoztatottak aránya az összes foglalkoztatottból, 2017-ben Forrás: a szerzö szerkesztése az Eurostat adatainak alapján 
A külföldi cégek esetén is azt látjuk, hogy a V4-országokban nagyon keveset költenek megtermelt új értékükből K + F-re, és kevés kutató-fejlesztőt alkalmaznak.

Az ábrák adatai egybehangzóan bizonyítják, hogy Magyarországon kevés az esélye annak is, hogy egy munkavállaló egy külföldi cégnél kutató-fejlesztő munkát végezhessen.

Ez összefüggésben lehet azzal, hogy a külföldi cégek általában a munkaigényes öszszeszerelő tevékenységeket telepítik a V4-országokba, így hozzánk is, és nem az innovativitást igénylő munkákat. A gazdasági szerkezet tudásigényességével kapcsolatos adatok alapján azt állapíthatjuk meg, hogy ahhoz, hogy több tudásalapú, a munkavállalók tudásbeli fejlődését segítő munkahely legyen, több innovatív cégre és több kutatás-fejlesztési ráfordításra van szükség a gazdaság egészében. A V4-ek adatainak összehasonlítását az 5. táblázatban látjuk.

5. táblázat: Az emberi fejlődés lehetőségeit meghatározó mutatók alapján a V4-országok sorrendje: gazdasági szerkezeti mutatók

\begin{tabular}{lcccc}
\hline \multicolumn{1}{c}{$\begin{array}{c}\text { Gazdasági szerkezeti } \\
\text { mutatók }\end{array}$} & Csehország & Magyarország & Lengyelország & Szlovákia \\
\hline $\begin{array}{l}\text { Innovatív cégek aránya } \\
\begin{array}{l}\text { K + F ráfordítások } \\
\text { a gazdaságban }\end{array}\end{array}$ & 1 & $\mathbf{3}$ & 4 & 2 \\
$\begin{array}{l}\text { A külföldi tulajdonú cégek } \\
\text { K + F ráfordításai }\end{array}$ & 1 & $\mathbf{2}$ & 3 & 4 \\
$\begin{array}{l}\text { A külföldi cégek K+ F } \\
\text { foglalkoztatása }\end{array}$ & 1 & $\mathbf{3}$ & 3 & 2 \\
$\begin{array}{l}\text { Első hely } \\
\text { Utolsó hely }\end{array}$ & 4 & $\mathbf{3}$ & 2 & 4 \\
\hline
\end{tabular}

Forrás: a szerző számitása

A táblázatban látható gazdasági szerkezeti mutatók alapján a cseh gazdaság kínálja a legnagyobb emberi fejlődési lehetőséget.

\section{Humán fenntarthatóság: mennyiségi és minőségi jellemzők}

A humán vagyonnal, humán tőkével kapcsolatos nemzetközi elemzések után térjünk rá a hazai adatok vizsgálatára nemzetközi összehasonlításban. Az adatokat mennyiségi és minőségi csoportba osztjuk tekintettel arra, hogy a lakosság számszerủ alakulása és minőségi jellemzői egyaránt fontosak a humán fenntarthatóság szempontjából.

39 Azért van eggyel több utolsó hely, mert a 3. mutatóra Magyarország és Lengyelország együtt szerepel az utolsó helyen. 


\section{Az emberi fejlödés mennyiségi mutatói: a lakosság számának alakulása}

A 6. ábrán a magyar lakosság számának változását látjuk 2004-2019 között.

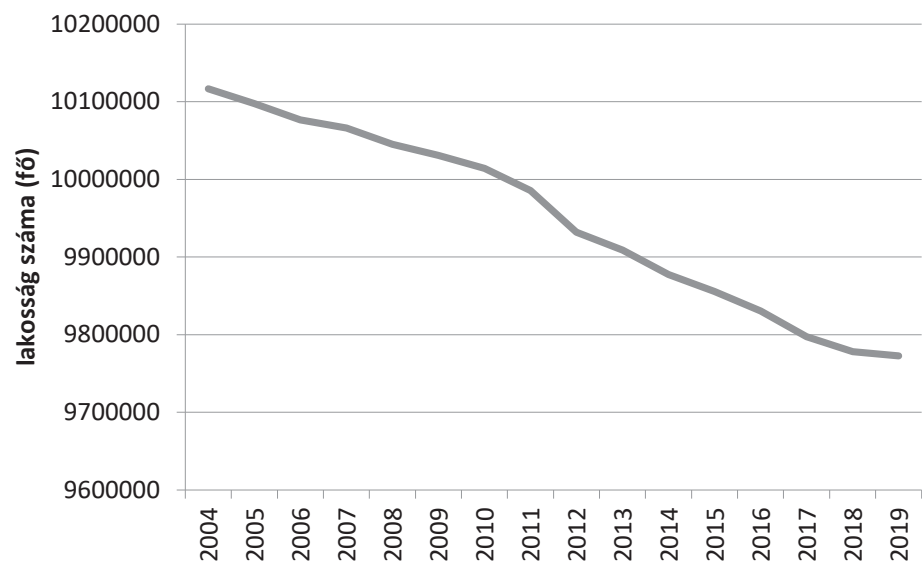

6. ábra: A magyar lakosság számának alakulása 2004-2019 között (fö)

Forrás: KSH 2019

A lakosságszám 2004-ről 2019-re 343986 fővel csökkent, ez évi átlagban 22932 fö, 2004-hez viszonyítva 3,4\%-nyi csökkenést jelent. Eközben Ausztria lakossága 8142573-ról 8858 775-re, azaz 716202 fővel nőtt. De nőtt Szlovákia és Csehország lakossága is: Csehországé 10195347 -ről 10649 800-ra, vagyis 454435 fővel, Szlovákiáé pedig 5371875 -ről 5450421 -re, azaz 78546 fővel.

A tendenciából azt a következtetést vonhatjuk le, hogy a humán fenntarthatóság, mennyiségi oldalról nálunk veszélyben van. A 7. ábrán az ezer lakosra jutó élve születési és halálozási adatokat látjuk 2010 és 2018 között.

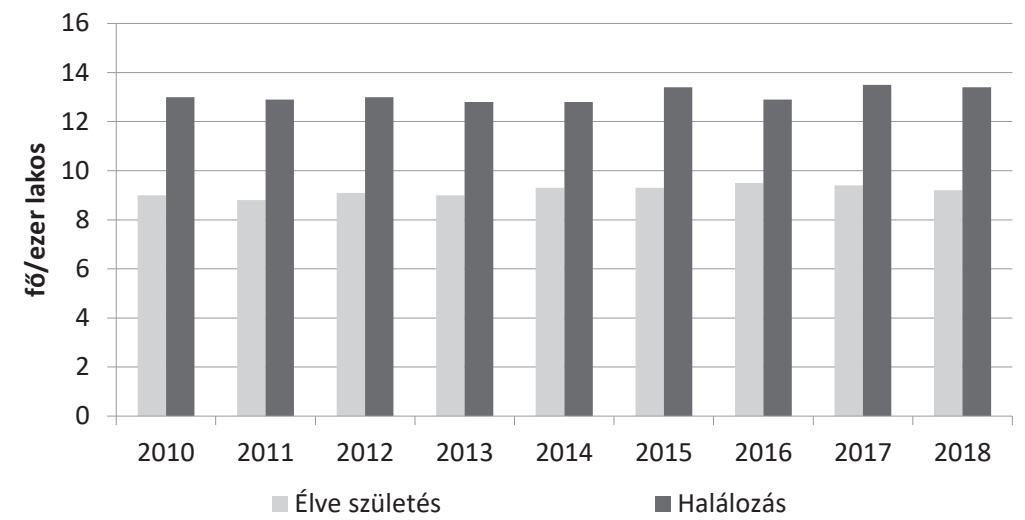

7. ábra: Ezer lakosra jutó élve születés és halálozás Magyarországon 2010-2018 Forrás: KSH 2019 
Az adatok gyengén javuló születésszámot és erősen romló halálozást mutatnak. A fogyás tehát jelentős mértékben függ a rossz halálozási adatoktól. A 8. ábrán 4 ország ${ }^{40}$ esetén látjuk az 1 évnél fiatalabb, továbbá az 55 és 60 éves lakosok számának alakulását 2015 és 2019 között.

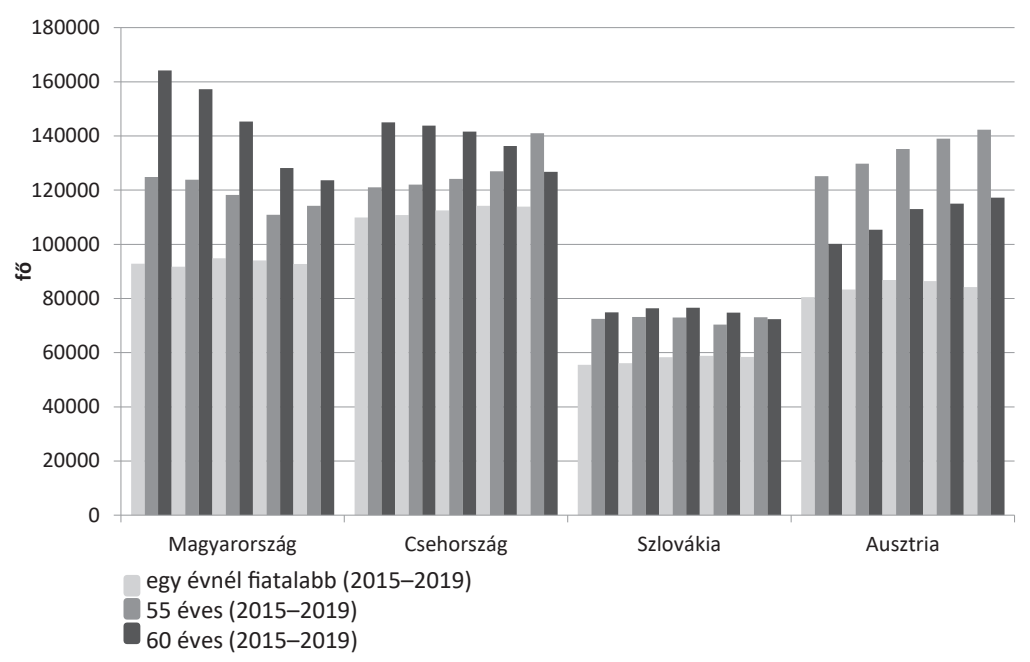

8. ábra: Az 1 évnél fiatalabb, az 55, valamint a 60 évesek számának alakulása a 2015-2019 közötti években

Forrás: a szerző szerkesztése az Eurostat adatainak alapján

Az adatok azt mutatják, hogy 2015 és 2019 között az 1 évnél fiatalabbak száma Magyarországon változóan alakult. Az 55 és 60 évesek száma viszont jelentősen csökkent. Ez érzékelteti a korai halálozási problémát. Az 1 évnél fiatalabbak száma a többi vizsgált országban folyamatosan nőtt, az 50 évesek száma Csehországban és Szlovákiában nőtt, a 60 éveseké csökkent. Ausztriában pedig mindkét időskorú csoport száma jelentősen nőtt. A születési és halálozási adatokkal összefüggésben fontos humán fenntarthatósági mutató a gyermeknépesség és az idős népesség eltartottsági aránya és az öregedési index.

A gyermeknépesség eltartottsági rátája azt mutatja meg, hogy mekkora a 0-14 éves korúak aránya az aktív korú, 15-64 éves népességen belül. Az idős népesség eltartottsági rátája pedig az időskorú (65 és afölötti) népesség arányát mutatja meg az aktív, 15-64 éves népességhez viszonyítva. A humán fenntarthatóság fontos jellemzője a korszerkezet, különösen a fiatalkorúak aránya. Az öregedési index az időskorú népességnek (65 és afölötti) a gyermekkorú népességhez (0-14 éves) mért arányát mutatja. Ezek a mutatók nemcsak országos, hanem regionális szintủ értéküket tekintve is figyelemre érdemesek.

40 Lengyelországot a jelentősen nagyobb lakosságszám miatt nem vizsgáljuk. 
6. táblázat: Eltartottsági ráták, öregedési index (jan.1., 2004-2019)

\begin{tabular}{|c|c|c|c|c|c|c|c|c|c|c|c|c|c|c|c|c|}
\hline Mutató/régió & 2004 & 2005 & 2006 & 2007 & 2008 & 2009 & 2010 & 2011 & 2012 & 2013 & 2014 & 2015 & 2016 & 2017 & 2018 & 2019 \\
\hline $\begin{array}{l}\text { A gyermek- } \\
\text { népesség } \\
\text { eltartottsági } \\
\text { rátája, \% }\end{array}$ & 23,1 & 22,8 & 22,4 & 22,1 & 21,8 & 21,6 & 21,5 & 21,3 & 21,1 & 21,1 & 21,2 & 21,4 & 21,6 & 21,7 & 21,9 & 22,0 \\
\hline Budapest & 17,9 & 17,9 & 17,9 & 17,9 & 18,1 & 18,2 & 18,5 & 18,8 & 18,4 & 18,9 & 19,4 & 19,8 & 20,2 & 20,3 & 20,4 & 20,4 \\
\hline Pest megye & 25,1 & 24,8 & 24,7 & 24,5 & 24,4 & 24,3 & 24,3 & 24,1 & 24,1 & 24,2 & 24,3 & 24,6 & 24,7 & 25,0 & 25,3 & 25,5 \\
\hline $\begin{array}{l}\text { Közép- } \\
\text { Dunántúl }\end{array}$ & 23,0 & 22,6 & 22,1 & 21,6 & 21,2 & 20,9 & 20,8 & 20,5 & 20,5 & 20,5 & 20,6 & 20,9 & 21,1 & 21,4 & 21,5 & 21,6 \\
\hline $\begin{array}{l}\text { Nyugat- } \\
\text { Dunántúl }\end{array}$ & 21,6 & 21,2 & 20,8 & 20,5 & 20,3 & 20,1 & 19,9 & 19,7 & 19,6 & 19,7 & 19,8 & 20,0 & 20,2 & 20,4 & 20,7 & 20,9 \\
\hline $\begin{array}{l}\text { Dél- } \\
\text { Dunántúl }\end{array}$ & 23,0 & 22,6 & 22,1 & 21,6 & 21,3 & 20,9 & 20,7 & 20,4 & 20,4 & 20,2 & 20,3 & 20,4 & 20,5 & 20,6 & 20,7 & 20,9 \\
\hline $\begin{array}{l}\text { Észak- } \\
\text { Magyar- } \\
\text { ország }\end{array}$ & 25,5 & 25,1 & 24,6 & 24,1 & 23,8 & 23,6 & 23,3 & 22,9 & 22,8 & 22,5 & 22,4 & 22,5 & 22,5 & 22,7 & 22,9 & 23,0 \\
\hline Észak-Alföld & 26,7 & 26,2 & 25,7 & 25,1 & 24,7 & 24,3 & 23,9 & 23,4 & 23,1 & 22,7 & 22,5 & 22,6 & 22,5 & 22,6 & 22,7 & 22,8 \\
\hline Dél-Alföld & 23,2 & 22,7 & 22,2 & 21,7 & 21,4 & 21,1 & 20,8 & 20,4 & 20,5 & 20,3 & 20,3 & 20,4 & 20,5 & 20,6 & 20,7 & 20,8 \\
\hline $\begin{array}{l}\text { Az idős } \\
\text { népesség } \\
\text { eltartottsági } \\
\text { rátája, \% }\end{array}$ & 22,6 & 22,7 & 22,9 & 23,2 & 23,5 & 23,8 & 24,2 & 24,4 & 24,6 & 25,1 & 25,8 & 26,5 & 27,2 & 27,9 & 28,5 & 29,3 \\
\hline Budapest & 25,9 & 26,0 & 26,1 & 26,3 & 26,6 & 26,8 & 27,1 & 27,2 & 27,5 & 28,0 & 28,5 & 28,8 & 29,3 & 29,8 & 30,2 & 31,0 \\
\hline Pest megye & 19,0 & 19,0 & 19,2 & 19,4 & 19,7 & 20,1 & 20,5 & 20,9 & 21,4 & 22,1 & 22,8 & 23,7 & 24,3 & 24,9 & 25,3 & 26,9 \\
\hline $\begin{array}{l}\text { Közép- } \\
\text { Dunántúl }\end{array}$ & 20,7 & 21,0 & 21,4 & 21,7 & 22,1 & 22,4 & 23,0 & 23,2 & 23,6 & 24,2 & 25,0 & 25,8 & 26,6 & 27,5 & 28,0 & 28,8 \\
\hline $\begin{array}{l}\text { Nyugat- } \\
\text { Dunántúl }\end{array}$ & 22,2 & 22,4 & 22,6 & 22,9 & 23,3 & 23,5 & 24,0 & 24,2 & 24,5 & 25,0 & 25,6 & 26,3 & 27,0 & 27,8 & 28,4 & 29,1 \\
\hline $\begin{array}{l}\text { Dél- } \\
\text { Dunántúl }\end{array}$ & 22,8 & 23,1 & 23,3 & 23,7 & 24,1 & 24,4 & 24,8 & 25,0 & 25,4 & 26,0 & 26,9 & 27,9 & 28,9 & 29,9 & 30,6 & 31,6 \\
\hline $\begin{array}{l}\text { Észak- } \\
\text { Magyar- } \\
\text { ország }\end{array}$ & 23,4 & 23,6 & 23,9 & 24,1 & 24,6 & 24,9 & 25,4 & 25,6 & 25,2 & 25,6 & 26,2 & 26,9 & 27,7 & 28,4 & 29,0 & 29,8 \\
\hline $\begin{array}{l}\text { Észak- } \\
\text { Alföld }\end{array}$ & 21,0 & 21,2 & 21,4 & 21,5 & 21,7 & 21,9 & 22,2 & 22,3 & 22,2 & 22,6 & 23,2 & 23,9 & 24,6 & 25,3 & 26,0 & 26,8 \\
\hline $\begin{array}{l}\text { Dél- } \\
\text { Alföld }\end{array}$ & 23,9 & 24,1 & 24,3 & 24,5 & 24,8 & 25,2 & 25,8 & 26,0 & 26,3 & 26,8 & 27,5 & 28,4 & 29,2 & 30,0 & 30,7 & 31,5 \\
\hline $\begin{array}{l}\text { Öregedési } \\
\text { index, \% }\end{array}$ & 97,6 & 99,9 & 102,4 & 104,9 & 107,6 & 109,9 & 112,6 & 114,7 & 116,4 & 118,9 & 121,5 & 123,6 & 126,1 & 128,5 & 130,2 & 132,9 \\
\hline Budapest & 144,2 & 145,5 & 146,1 & 146,8 & 147,1 & 147,1 & 146,6 & 144,8 & 149,1 & 147,8 & 146,6 & 145,2 & 145,2 & 146,6 & 148,5 & 152,3 \\
\hline Pest megye & 75,8 & 76,8 & 77,9 & 79,2 & 80,6 & 82,4 & 84,6 & 86,7 & 89,0 & 91,3 & 93,9 & 96,2 & 98,4 & 99,7 & 100,3 & 101,8 \\
\hline $\begin{array}{l}\text { Közép- } \\
\text { Dunántúl }\end{array}$ & 90,1 & 93,2 & 96,9 & 100,6 & 104,2 & 107,2 & 110,4 & 113,2 & 115,1 & 118,0 & 120,9 & 123,6 & 125,7 & 128,5 & 130,3 & 133,1 \\
\hline $\begin{array}{l}\text { Nyugat- } \\
\text { Dunántúl }\end{array}$ & 102,9 & 105,5 & 108,6 & 111,5 & 114,8 & 116,9 & 120,3 & 122,8 & 124,6 & 127,0 & 129,3 & 131,3 & 133,5 & 136,1 & 137,3 & 138,9 \\
\hline $\begin{array}{l}\text { Dél- } \\
\text { Dunántúl }\end{array}$ & 99,4 & 102,1 & 105,5 & 109,4 & 113,3 & 116,4 & 120,1 & 122,7 & 124,7 & 128,7 & 132,6 & 136,3 & 140,9 & 144,9 & 147,3 & 151,2 \\
\hline $\begin{array}{l}\text { Észak- } \\
\text { Magyar- } \\
\text { ország }\end{array}$ & 91,8 & 94,3 & 97,0 & 99,9 & 103,3 & 105,8 & 109,3 & 111,5 & 110,8 & 114,0 & 117,0 & 119,5 & 122,8 & 125,1 & 126,8 & 129,5 \\
\hline $\begin{array}{l}\text { Észak- } \\
\text { Alföld }\end{array}$ & 78,7 & 80,9 & 83,4 & 85,6 & 87,9 & 90,2 & 92,9 & 95,3 & 96,2 & 99,5 & 103,0 & 105,9 & 109,1 & 111,9 & 114,6 & 117,4 \\
\hline $\begin{array}{l}\text { Dél- } \\
\text { Alföld }\end{array}$ & 102,8 & 106,0 & 109,3 & 112,7 & 116,3 & 119,7 & 123,9 & 127,2 & 128,4 & 131,9 & 135,4 & 138,8 & 142,3 & 145,8 & 148,1 & 151,4 \\
\hline
\end{tabular}

Forrás: KSH 2019 
A táblázatból egyrészt az rajzolódik ki, hogy országos szinten csökken a gyermeknépesség eltartottsági rátája és nő az idős népesség eltartottsági rátája. Ez fenntarthatósági szempontból rossz tendencia. Különösen figyelemre érdemes a jelentős romlást mutató öregedési index. Fel kell ugyanakkor figyelni a regionális különbségekre. Az öregedési index romlása különösen a fejlett gazdaságú Budapesten, továbbá DélDunántúlon és Dél-Alföldön jellemző. Dél-Dunántúlon és Dél-Alföldön a mutató felgyorsuló romlására érdemes felfigyelni. Az öregedési index az Észak-Alföldön a legkedvezőbb, ami összhangban van az idős népesség alacsonyabb eltartottsági rátájával.

A gyermeknépesség eltartottsági rátája egyedül Budapesten és Pest megyében mutat némi javulást. Végső soron ezek az adatok arra figyelmeztetnek, hogy a lakosságszám fizikai fenntarthatósága, ahogyan a többi demográfiai mutató esetén is látható, veszélyben van.

Végül, összefüggésben az eddigi adatokkal, vizsgáljuk meg nemzetközi összehasonlításban az egészségben várható élettartamot és az 50 éves korúak esetén még egészségesen várható élettartamot a V4-országokban.

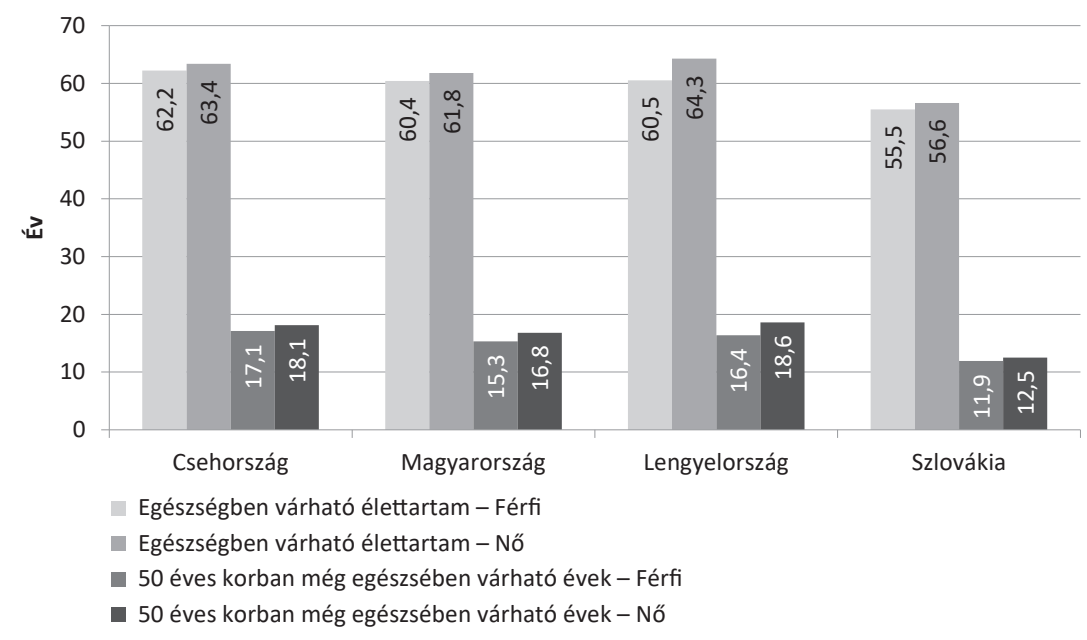

9. ábra: Egészségben várható élettartam és 50 éves korban még egészségben tölthető évek száma (2018. év)

Forrás: a szerző szerkesztése az Eurostat adatainak alapján

Az ábra alapján azt látjuk, hogy az egészségben várható élettartam a V4-országokon belül, férfiak és nők esetén egyaránt Magyarországon a második legrövidebb. Ugyanez a helyzet az 50 éves korban még egészségben várható élettartam esetén. A humán fenntarthatóság mennyiségi mutatói arra hívják fel a figyelmet, hogy ezen a területen megoldandó problémák vannak. Fel kell figyelni a regionális különbségekre is, mert azok további társadalmi fenntarthatósági problémákat érzékeltetnek.

Hiába nő tehát folyamatosan és látványosan a gazdaság, ha közben fogy a lakosság, a még bőven munkaképes korú emberek közül pedig sokan nagyon korán meghalnak. 
De mi a helyzet a tudásjellemzőkkel? Vizsgáljuk most meg az iskolázottsági, tudásnövekedési és -fenntartási adatokat.

\section{A humán fenntarthatóság minőségi jellemzői: tudásmutatók}

A tudással, képzettséggel kapcsolatos jellemzőket 4 mutatóval elemezzük. Ezek:

- a felsőfokú végzettségűek aránya,

- a tudományos végzettségűek aránya,

- a továbbképzésben részt vevők aránya,

- az iskolából kimaradók aránya.

A 10. ábrán két korcsoportra bontva látjuk a felsőfokú végzettségủek arányát. Arra kell felfigyelni, hogy a fiatal korcsoportban - a 25-34 évesek - a vizsgált országok között Magyarországon a legalacsonyabb a felsőfokú végzettségủek aránya. Pedig ez a korcsoport foglalkoztatási szempontból kiemelkedően fontos, ráadásul még legalább további 35-40 évig dolgozik majd.

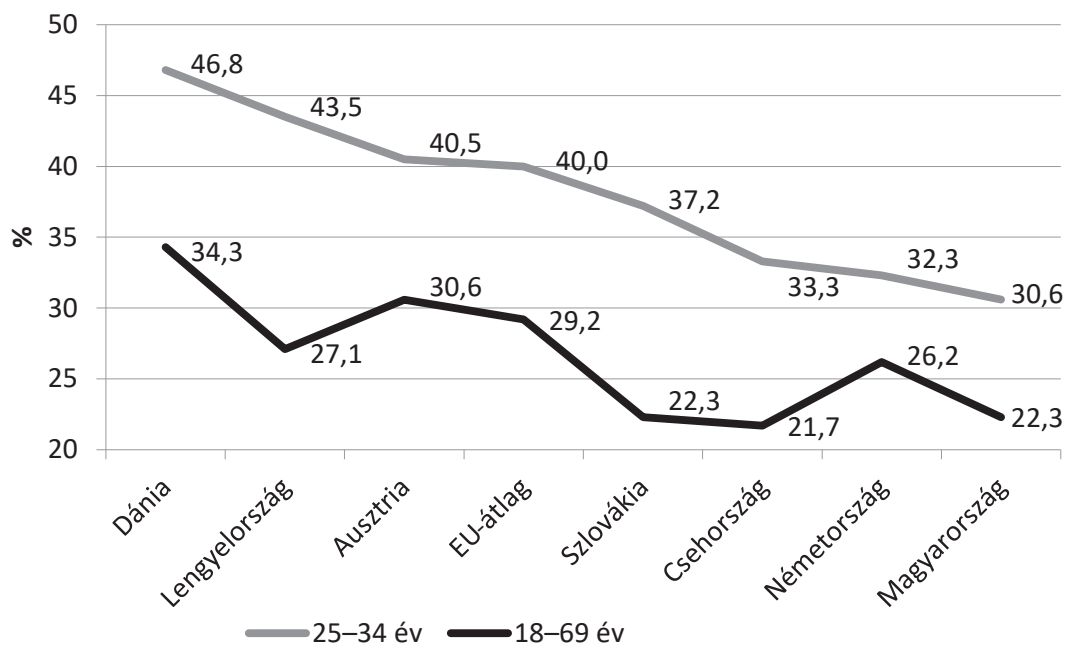

10. ábra: Felsőfokú végzettségüek aránya (25-34 és 18-69 év) korcsoportokban, néhány országban, 2018-ban

Forrás: a szerzö szerkesztése az Eurostat adatainak alapján

Azt is észrevehetjük, hogy mindkét korcsoport esetén a fejlett gazdaságú országok között az EU egyik legversenyképesebb országának, Dániának az adatai kiemelkedően jók.

Lényeges az is, hogy mennyi a felsőfokú végzettségűek között a természettudományos végzettségűek aránya a fiatal korcsoportban. Az Eurostat adatait látjuk a 11. ábrán 1000 lakosra vetítve és a 20-29 éves korcsoportra. 


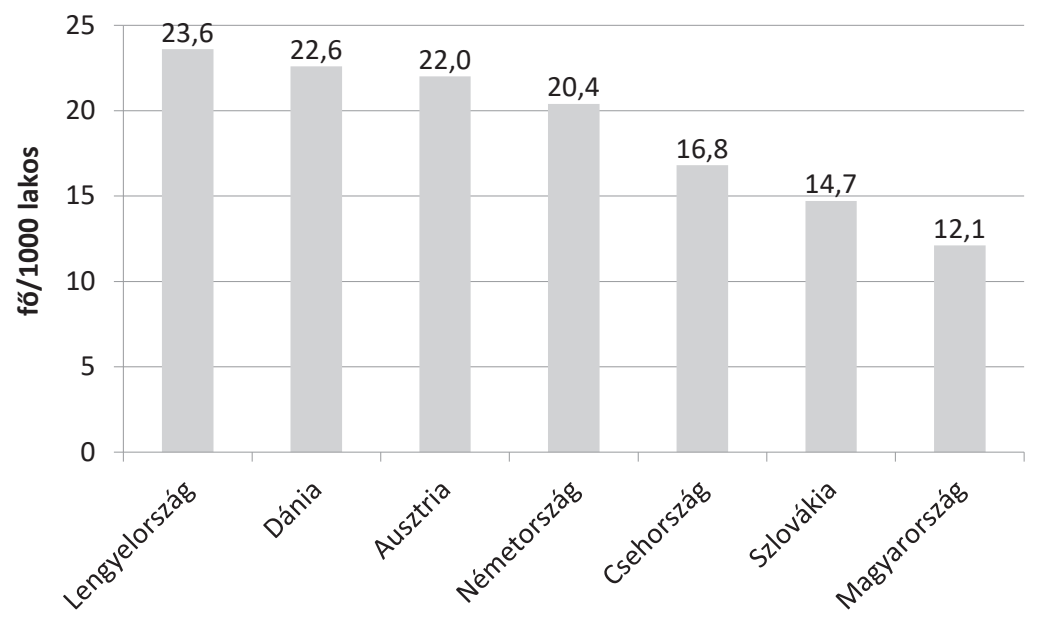

11. ábra: Felsőfokú végzettségüek természettudományos, matematika, statisztika, infokommunikáció, müszaki, gyártási és épitésügyi szakterületeken

(20-29 éves korosztály, fó/1000 lakosra vetítve, 2017)

Forrás: a szerző szerkesztése az Eurostat adatainak alapján

A magyar adat, mint látjuk, a legrosszabb. Ez azért különösen figyelemre érdemes, mert ezek a szakterületek azok, amelyeken a jövőben nagyon nagy szükség lesz képzett szakemberekre. A 12. ábra a tudásszerzés dinamizmusát tükrözi. Azt, hogy milyen arányban vesznek részt a felnőttek folyamatos tanulásban, továbbképzésben.

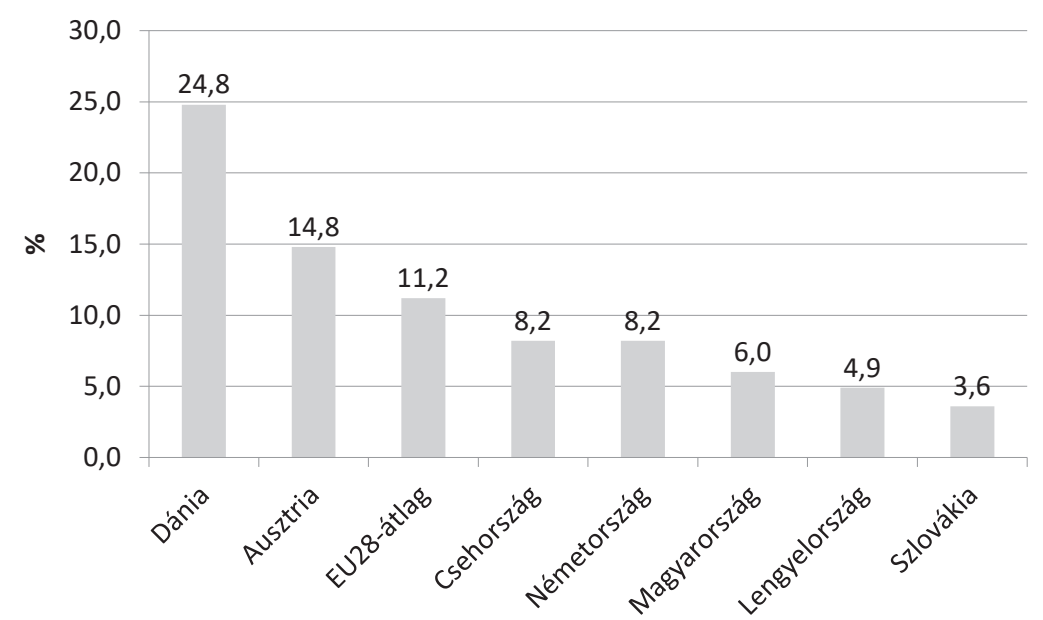

12. ábra: Továbbképzésben részt vettek aránya ${ }^{41}$ (25-64 éves korcsoport, 2019, \%) Forrás: a szerzö szerkesztése az Eurostat adatainak alapján

41 A mutató mérése kikérdezéssel történik. A megkérdezés előtti egy hónapon belüli továbbképzésben való részvételre kérdeznek rá. 
A 12. ábra azt szemlélteti, hogy e tekintetben valamennyi V4-ország nagyon rosszul áll. Viszont ismét Dánia adata kiemelkedően jó. A felnőttképzést, a folyamatos tanulást szükségessé teszik a technológiai változások, az új tudás, új ismeretek megjelenése, amire az egész társadalomnak fel kell készülnie.

Ugyanennyire fontos az is, hogy a fiatalok ne hagyják abba a tanulást. A 7. táblázatban az iskolából 18-24 éves korcsoportban kimaradók arányát látjuk 2008-ban, illetve 2015-2019 között.

7. táblázat: Az iskolából kimaradók aránya a 18-24 éves korcsoportban (\%)

\begin{tabular}{lrrrrrr}
\hline \multicolumn{1}{c}{ Ország } & $\mathbf{2 0 0 8}$ & $\mathbf{2 0 1 5}$ & $\mathbf{2 0 1 6}$ & $\mathbf{2 0 1 7}$ & $\mathbf{2 0 1 8}$ & $\mathbf{2 0 1 9}$ \\
\hline Csehország & 5,6 & 6,2 & 6,6 & 6,7 & 6,2 & 6,2 \\
Magyarország & 11,7 & 11,6 & 12,4 & 12,5 & 12,5 & 12,0 \\
Lengyelország & 5,0 & 5,3 & 5,2 & 5,0 & 4,8 & 5,1 \\
Szlovákia & 6,0 & 6,9 & 7,4 & 9,3 & 8,6 & 8,0 \\
Ausztria & 10,2 & 7,3 & 6,9 & 7,4 & 7,3 & 7,5 \\
Németország & 11,8 & 10,1 & 10,3 & 10,1 & 10,3 & 10,4 \\
Dánia & 12,7 & 8,1 & 7,5 & 8,8 & 10,4 & 10,1 \\
\hline
\end{tabular}

Forrás: a szerző szerkesztése az Eurostat adatainak alapján

2008-ban még a magyar adat alulról a 3. volt, 2019-re azonban már a legrosszabb értéket érte el a vizsgált országok között. Figyelemre érdemes a többi V4-ország sokkal jobb adata, és a viszonylag gyenge - bár javuló tendenciát mutató - német és dán adat.

Végül nézzük meg, mennyit költöttek a GDP-jük arányában a V4-országok, Ausztria és Németország 2016-ban ${ }^{42}$ felsőoktatásra (13. ábra).

Azt látjuk, hogy a V4-országok adatai sokkal alacsonyabbak, mint a két fejlett országé. Az adatok ráadásul elrejtik azt a tényt, hogy Ausztria és Németország GDP-je sokkal magasabb, mint a V4-országoké, így az abszolút értékekben még nagyobbak a különbségek.

A képzettségi, tudásbeli adatok összehasonlításával arra a következtetésre juthatunk, hogy a humán vagyon minőségi fenntarthatósága is veszélyeket érzékeltet. Azt látjuk ugyanis, hogy a vizsgált tudásadatok tekintetében gyakran nemcsak a fejlett országokhoz, hanem a többi V4-es országhoz képest is elmaradásban vagyunk, aminek okai között megtalálhatjuk azt is, hogy keveset költünk felsőoktatásra. De természetesen kutatni kell a további okokat is. Például azt, hogy nálunk miért nem népszerübbek a tudományos pályák, miért nem jellemzőbb az állandó tanulás, illetve, hogy miért hagyják abba sokan befejezés előtt a tanulást.

A humán fenntarthatóság e minőségi mutatói a gazdasági fenntarthatóságot, a gazdasági szerkezet minőségi javulását is gátolják.

42 Ez a legutolsó elérhető adat az Eurostatban. 


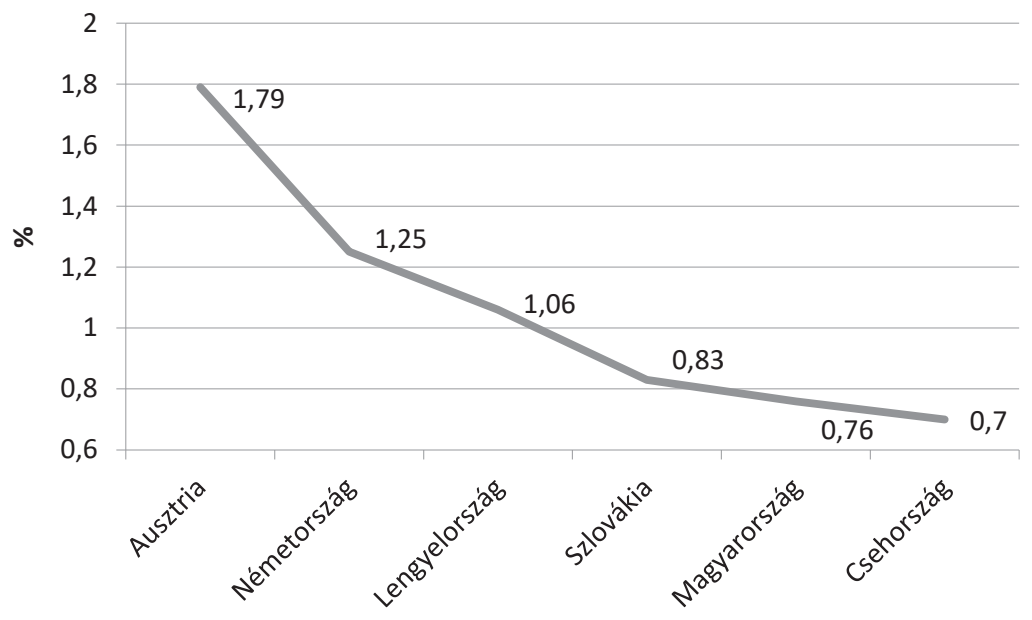

13. ábra: A felsőoktatásra szánt ráforditás a GDP arányában (\%) Forrás: a szerző szerkesztése az Eurostat adatainak alapján

Befejezésként nézzünk meg még egy, a humán fenntarthatóság szempontjából fontos mutatót, a fiatalkorúak munkanélküliségének alakulását. A fiatalkorúak munkanélkülisége különösen veszélyes társadalmi jelenség, mivel már nagyon korán gátolja az emberi fejlődést. A 14. ábrán, V4-es összehasonlításban látjuk a 25 évnél fiatalabbak munkanélküliségi adatainak változását 2014 és 2019 között.

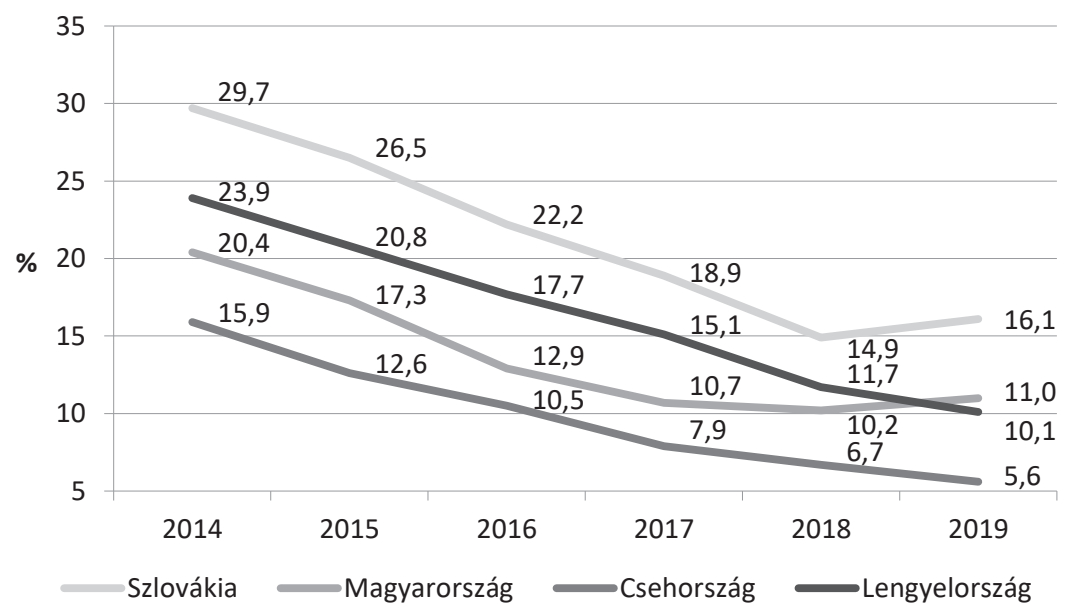

14. ábra: Fiatalkorúak - 25 év alattiak - munkanélküliségének változása a V4-országokban (az aktív lakosság \%-ában)

Forrás: a szerző szerkesztése az Eurostat adatainak alapján 
Az adatok azt mutatják, hogy minden országban csökkent 2014 és 2019 között a fiatalkorú munkanélküliek aránya, de Csehországban és Lengyelországban erőteljesebb volt a javulás. Magyarországon 2017-2018-hoz képest 2019-ben romlott az adat. A 8. táblázat szerint az emberi fejlődés összefoglaló tudásmutatói alapján a V4ek között Magyarország egyetlen mutató alapján sincs az élen. Vezető pozícióban Lengyelország és Csehország van.

8. táblázat: Az emberi fejlödési lehetöségek minőségi (humán) mutatói a V4-országokban

\begin{tabular}{lcccc}
\hline \multicolumn{1}{c}{ Mutató } & Csehország & Magyarország & Lengyelország & Szlovákia \\
\hline $\begin{array}{l}\text { Egészségben várható } \\
\text { élettartam }\end{array}$ & & & & \\
$\quad 1$ & 3 & 1 & 4 \\
férfi & 2 & $\mathbf{3}$ & & 4 \\
$\quad$ nő & & & & \\
\hline $\begin{array}{l}50 \text { éves korban még } \\
\text { egészségesen várható }\end{array}$ & & & 2 & 4 \\
élettartam & 1 & $\mathbf{3}$ & 1 & 4 \\
férfi & 2 & $\mathbf{3}$ & & \\
nő & & & & \\
\hline
\end{tabular}

Felsőfokú végzettségűek

aránya

\begin{tabular}{llccc}
$\begin{array}{l}25-34 \text { év } \\
18-69 \text { év }\end{array}$ & 3 & $\mathbf{4}$ & 1 & 2 \\
\hline $\begin{array}{l}\text { Továbbképzésben } \\
\text { részt vevők aránya }\end{array}$ & 1 & $\mathbf{2}$ & 1 & $2^{43}$ \\
\hline $\begin{array}{l}\text { Iskolaelhagyók aránya } \\
\text { Felsőoktatási ráfordítás }\end{array}$ & 2 & $\mathbf{2}$ & 3 & 4 \\
\hline $\begin{array}{l}\text { Fiatalkorúak } \\
\text { munkanélkülisége }\end{array}$ & 4 & $\mathbf{4}$ & 1 & 3 \\
\hline $\begin{array}{l}\text { Legelső helyek } \\
\text { Legutolsó helyek }\end{array}$ & 4 & 3 & 1 & 2 \\
\hline
\end{tabular}

Forrás: a szerző szerkesztése és számítása

43 A magyar és szlovák érték egyezik. 


\section{Az emberi fejlódés társadalmi-fenntarthatósági mutatói}

Bár a társadalmi fenntarthatóságnak nem kizárólagos mutatója az anyagi helyzet, de azért arra nézve következtetéseket lehet belőle levonni, hogy mennyire jut esélye a lakosságnak tudása, egészségi állapota javítására, kulturálódásra, pihenésre. Az abszolút értéken kívül annak megoszlása is fontos mutató. A 15. ábrán az egy lakosra jutó GDP-értéket látjuk a V4-országokban 2017-ben, folyóáron (euro/fö). A 9. táblázat pedig a magyar adatokat mutatja regionális bontásban.

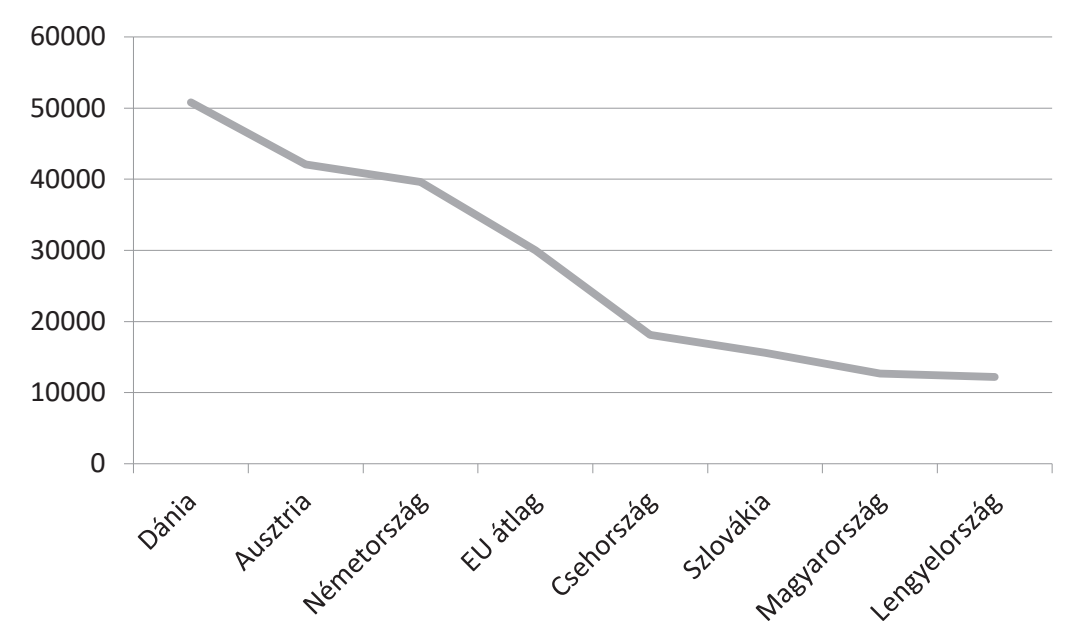

15. ábra: Egy före jutó GDP (folyóáron, euro/fö, 2017) Forrás: a szerzö szerkesztése az Eurostat adatainak alapján

9. táblázat: Egy före jutó GDP a magyar régiókban (folyóáron, euro/fó, 2010, 2017)

\begin{tabular}{lrc}
\hline \multicolumn{1}{c}{ Ország/régió } & $\mathbf{2 0 1 0}$ & $\mathbf{2 0 1 7}$ \\
\hline Magyarország & 9900 & 12700 \\
Budapest & 22000 & 26100 \\
Pest megye & 8600 & 10000 \\
Közép-Dunántúl & 8600 & 11700 \\
Nyugat-Dunántúl & 9800 & 13400 \\
Dél-Dunántúl & 6700 & 8400 \\
Észak-Magyarország & 5900 & 8500 \\
Észak-Alföld & 6300 & 8100 \\
Dél-Alföld & 6400 & 9000 \\
\hline
\end{tabular}

Forrás: a szerzö szerkesztése az Eurostat adatainak alapján 
A 16. ábrán az egy főre jutó GDP-t vásárlóerő-paritáson mérve az EU átlag \%-ában látjuk a V4-ekre, Ausztriára, Németországra és Dániára, továbbá a magyar régiókban.

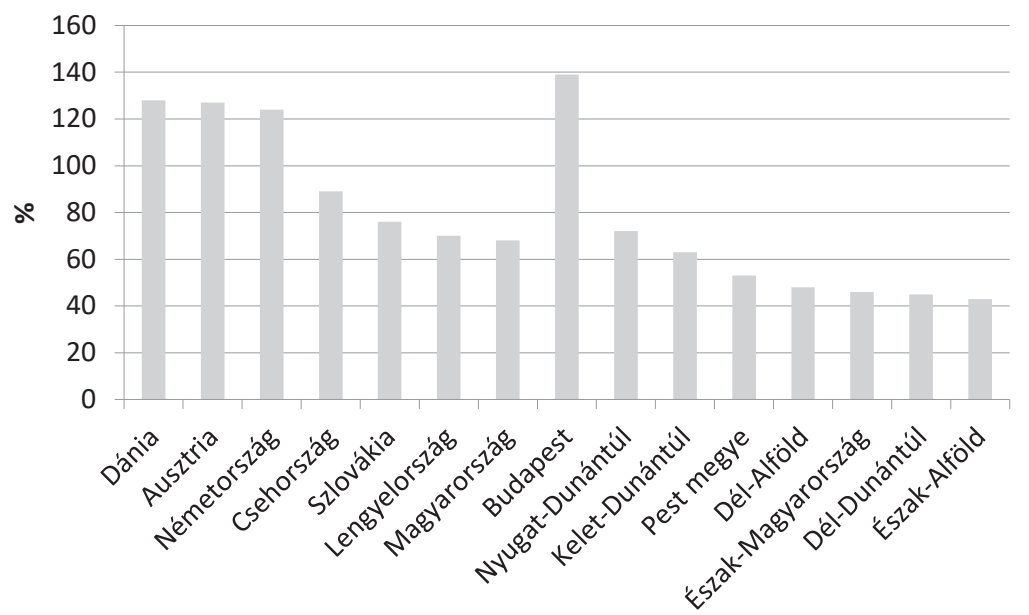

16. ábra: Egy fóre jutó GDP (PPS) az EU átlag \%-ában, 2017, országok és magyar régiók Forrás: a szerző szerkesztése az Eurostat adatainak alapján

Végül a 17. ábra pedig az egy főre jutó elkölthető nettó jövedelmet szemlélteti (euro/fő).

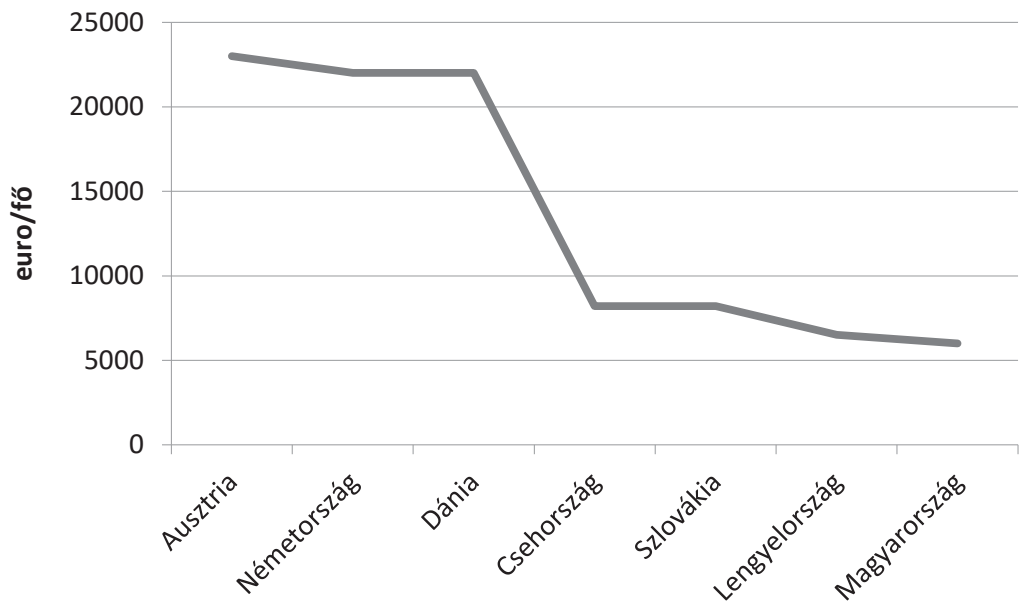

17. ábra: Egy före jutó elkölthetö nettó jövedelem (euro/fö, 2016) Forrás: a szerző szerkesztése az Eurostat adatainak alapján

A társadalmi fenntarthatóság szempontjából fontos jövedelmi adatok a V4-országok és közöttük Magyarország jelentős lemaradását mutatják a fejlett országokhoz képest. Magyarország esetén a regionális eltérésekre is fel kell figyelni. Hiszen pél- 
dául az észak-alföldi régió egy főre jutó GDP-adata a budapesti érték csupán 31\%-a (16. ábra).

A regionális különbségeket szemlélteti a 10. táblázat is, amely 2010 és 2017-ben mutatja meg Magyarország és régiói egy főre jutó folyóáron mért GDP-értékének változását, rámutatva arra, hogy a regionális különbségek nemcsak az EU-s átlag \%-ában, hanem az abszolút értékek vonatkozásában is jelentősek. A regionális fejlettségi kiegyenlítetlenség nemcsak gazdasági, hanem humán és társadalmi fenntarthatósági problémákat is érzékeltet, és ronthatja a társadalmi harmóniát. Fontos feladat ezért a különbségek csökkentése, az elmaradt régiók felzárkóztatása a humán tőke helyi erősítésével. Végül ejtsünk szót a jövedelemi különbségekről, illetve azok alakulásáról is. A jövedelmi különbségeket az úgynevezett GINI-indexszel mérik. Ennek értéke 0-100 között lehet. A teljes egyenlőség esetén értéke 0, a teljes egyenlőtlenség esetén 100. Minél alacsonyabb egy adott ország esetén az érték, annál kisebbek a jövedelmi egyenlőtlenségek. A 10. táblázatban a GINI-index alakulását látjuk 2005-ben, illetve 2014-2018 között a V4-országokban, Ausztriában, Németországban, Dániában és az EU-ban átlagosan.

10. táblázat: A GINI-index alakulása (2005, 2014-2018)

\begin{tabular}{lcccccc}
\hline \multicolumn{1}{c}{ Ország } & $\mathbf{2 0 0 5}$ & $\mathbf{2 0 1 4}$ & $\mathbf{2 0 1 5}$ & $\mathbf{2 0 1 6}$ & $\mathbf{2 0 1 7}$ & $\mathbf{2 0 1 8}$ \\
\hline Csehország & 26,0 & 25,1 & 25,0 & 25,1 & 24,5 & 24,0 \\
Magyarország & 27,6 & 28,6 & 28,2 & 28,2 & 28,1 & 28,7 \\
Lengyelország & 35,6 & 30,8 & 30,6 & 29,8 & 29,2 & 27,8 \\
Szlovákia & 26,2 & 26,1 & 23,7 & 24,3 & 23,2 & 20,9 \\
Ausztria & 26,3 & 27,6 & 27,2 & 27,2 & 27,9 & 26,8 \\
Németország & 26,1 & 30,7 & 30,1 & 29,5 & 29,1 & 31,1 \\
Dánia & 23,9 & 27,7 & 27,1 & 27,7 & 27,6 & 27,8 \\
EU28 & - & 31,0 & 31,0 & 30,8 & 30,6 & 30,9 \\
\hline
\end{tabular}

Forrás: a szerző szerkesztése az Eurostat adatainak alapján

Azt látjuk, hogy a V4-országokban az EU-s átlagértéknél alacsonyabbak a jövedelmi különbségek. Németországban és Dániában 2005-höz képest jelentős növekedés következett be. Magyarországon 27,6-ról 28,7-re nőtt az index értéke. A legnagyobb jövedelemegyenlőtlenség az egész EU-ban 2018-ban Bulgáriában $(39,6)$ és Litvániában $(36,9)$, a legalacsonyabb pedig Szlovákiában $(20,9)$, Szlovéniában $(23,4)$ és Csehországban $(24,0)$ volt.

$\mathrm{Az} \mathrm{OECD}^{44}$ a jövedelemegyenlőtlenségen kívül a vagyonegyenlőtlenséget is vizsgálja. Azt méri, hogy a vagyon hogyan oszlik meg a társadalomban. Azonban a legutolsó rendelkezésre álló adat a legtöbb ország esetében a 2014. évi. Az idősoros elemzések

44 OECD: Gazdasági Együttműködési és Fejlesztési Szervezet, 36 tagállammal. Székhelye: Franciaország, Párizs. 
azt bizonyítják, hogy a vagyoni egyenlőtlenségek nagyobbak, mint a jövedelmi egyenlőtlenségek. A jövedelmi és vagyoni egyenlőtlenségek növekedése egyaránt társadalmi fenntarthatósági problémára utal. Hiszen a szétszakadó társadalom nem segíti a humán fejlődést, a tudás, a képességek szintjének emelkedését, és gátolja a társadalmi harmónia kialakulását, a társadalom egyenletes, minőségi fejlődését is. Most foglaljuk össze a társadalmi fenntarthatósági mutatók szerinti országrangsort a V4-országokra. Ezt látjuk a 11. táblázatban.

11. táblázat: Az emberi fejlödés társadalmi fenntarthatósági mutatói a V4-országokban

\begin{tabular}{lcccc}
\hline & Csehország & Magyarország & Lengyelország & Szlovákia \\
\hline $\begin{array}{l}\text { Egy före jutó GDP } \\
\text { (euro) }\end{array}$ & 1 & 3 & 4 & 2 \\
$\begin{array}{l}\text { Egy före jutó GDP } \\
\text { az EU28 \%-ában }\end{array}$ & 1 & $\mathbf{4}$ & 3 & 2 \\
$\begin{array}{l}\text { Egy före jutó elkölthető } \\
\text { nettó jövedelem }\end{array}$ & 1 & $\mathbf{3}$ & 2 & $1^{45}$ \\
$\begin{array}{l}\text { GINI-index } \\
\text { Legelső hely }\end{array}$ & 2 & $\mathbf{4}$ & 3 & 1 \\
Legutolsó hely & 3 & - & - & 1 \\
\hline
\end{tabular}

Forrás: a szerző számítása

A vizsgált mutató közül három esetében Csehország vezet, Magyarország pedig három mutatóban is az utolsó helyen van.

\section{Összefoglalás, következtetések}

A fenntarthatóság a jövőről, a hosszútávról szól. Arról, hogy mit teszünk ma azért, hogy a gazdaság, a társadalom, a környezet a jövőben is - egyaránt erősödve- kiegyensúlyozottan fejlődjék.

Ez a cikk elsősorban a humán és társadalmi fenntarthatóság egyes szeleteit elemezte rámutatva arra, hogy a gazdasági eredmények önmagukban nem biztosítják sem a humán, sem a társadalmi fejlődést. A gazdasági fenntarthatóság fontos cél, de azt nem lehet a hagyományos növekedési mutatóval, a GDP-vel mérni. A gazdasági fenntarthatóság lényege, a mennyiségi növekedéssel szemben a minőségi, szerkezeti fejlődés, amely támaszkodik a humán fejlődésre és egyben erősíti a társadalmi fenntarthatóságot.

Végezetül vessük össze valamennyi mutató együttes értékelése alapján a V4-országok pozícióit, és tegyük mellé a gazdasági növekedés GDP-mutatóját!

45 Egyező érték. 
12. táblázat: A V4-országok GDP-növekedési mutatói: 2015-2019

\begin{tabular}{lccccc}
\hline \multicolumn{1}{c}{ Ország } & $\mathbf{2 0 1 5}$ & $\mathbf{2 0 1 6}$ & $\mathbf{2 0 1 7}$ & $\mathbf{2 0 1 8}$ & $\mathbf{2 0 1 9}^{\mathbf{4 6}}$ \\
\hline Csehország & 5,3 & 2,5 & 4,4 & 2,8 & 2,5 \\
Magyarország & 3,8 & 2,2 & 4,3 & 5,1 & 4,0 \\
Lengyelország & 3,8 & 3,1 & 4,9 & 5,1 & 4,0 \\
Szlovákia & 4,8 & 2,1 & 3,0 & 4,0 & 2,3 \\
\hline \multirow{2}{*}{ Első helyek } & Csehország & \multirow{2}{*}{ Lengyelország } & Lengyelország & $\begin{array}{c}\text { Magyarország, } \\
\text { Lengyelország }\end{array}$ & \multirow{2}{*}{ Magyarország } \\
\hline \multirow{2}{*}{ Utolsó helyek } & Lengyelország, & \multirow{2}{*}{ Szlovákia } & Szlovákia & Csehország & \multirow{2}{*}{ Szlovákia } \\
\hline
\end{tabular}

Forrás: a szerző szerkesztése az Eurostat adatainak alapján

13. táblázat: A V4-országok fenntarthatósági helyezéseinek összefoglalása

\begin{tabular}{lcccccccc}
\hline & \multicolumn{2}{c}{ Csehország } & \multicolumn{2}{c}{ Magyarország } & \multicolumn{2}{c}{ Lengyelország } & \multicolumn{2}{c}{ Szlovákia } \\
\cline { 2 - 9 } Mutatócsoport & $\begin{array}{c}\text { első } \\
\text { hely }\end{array}$ & $\begin{array}{c}\text { utolsó } \\
\text { hely }\end{array}$ & $\begin{array}{c}\text { elsö } \\
\text { hely }\end{array}$ & $\begin{array}{c}\text { utolsó } \\
\text { hely }\end{array}$ & $\begin{array}{c}\text { első } \\
\text { hely }\end{array}$ & $\begin{array}{c}\text { utolsó } \\
\text { hely }\end{array}$ & $\begin{array}{c}\text { első } \\
\text { hely }\end{array}$ & $\begin{array}{c}\text { utolsó } \\
\text { hely }\end{array}$ \\
\hline $\begin{array}{l}\text { Gazdasági szer- } \\
\text { kezeti mutatók }\end{array}$ & 4 & - & - & $\mathbf{1}$ & - & 2 & - & 2 \\
$\begin{array}{l}\text { Humán mutatók } \\
\text { (mennyiségi }\end{array}$ & 4 & 2 & - & $\mathbf{2}$ & 6 & - & - & 6 \\
$\begin{array}{l}\text { és minőségi) } \\
\begin{array}{l}\text { Társadalmi } \\
\text { fenntarthatóság }\end{array}\end{array}$ & 3 & - & - & $\mathbf{3}$ & - & 1 & 1 & - \\
\hline Összesítve & 11 & 2 & - & $\mathbf{6}$ & 6 & 3 & 1 & 8 \\
\hline
\end{tabular}

Forrás: a szerző szerkesztése

A 12. táblázatban azt látjuk, hogy a gazdasági növekedési mutató tekintetében Magyarország jó helyzetben van a V4-országok között. Az utolsó két évben első helyen is van. Viszont a fenntarthatósági mutatók esetén Csehország messze megelőzi a többi V4-országot. Magyarország egyetlen mutatóban sincs az első helyen, viszont 6 esetben az utolsó. Ennél rosszabb adata csak Szlovákiának van. Az adatok szerint tehát a magyar GDP-vel mért gazdasági növekedés nem erősíti a fenntarthatósági mutatókat. Elsősorban a humán és a társadalmi fenntarthatóságban nagy a magyar lemaradás. Arra érdemes felfigyelni, hogy a versenyképességi és innovációs listákon mindenhol Csehország vezet, ami bizonyítja, hogy a versenyképességhez és innovációhoz nem elég a gazdasági növekedés, humán és társadalmi fejlődésre is szükség van.

A tanulság Magyarország számára, hogy a GDP-mutató növekedése mellett nagyobb figyelmet kell fordítani a humán és társadalmi tényezőkre is, azaz a befektetéseket jobban kell megosztani a fizikai, gépi és egyéb műszaki jellegű területek és az emberekbe, a tudásnövelésbe, a társadalmi fejlődésbe való beruházások között.

46 A 2019. évi adatok előrejelzések. 
Továbbá nagyon fontos az is, hogy a gazdasági szerkezet fejlődése olyan irányt vegyen, amely lehetővé teszi a jobb, minőségibb, több tudást és kreativitást igénylő munkahelyek létrejöttét, és ezzel azt, hogy a magyar humán vagyon minél inkább kiteljesedhessen, fejlődhessen.

\section{Felhasznált irodalom}

Daly, Herman E. (1996): Beyond Growth: The Economics of Sustainable Development. Boston, Beacon Press.

Daly, Herman E. - Совв, John B. (1989): For the Common Good. Boston, Beacon Press.

2019 Europe Sustainable Development Report (2019). Sustainable Development Solutions Network. Institute for European Environmental Policy.

Europa 2020. Az intelligens, fenntartható és inkluzív növekedés stratégiája. Európai Bizottság. 2010.3.3. [COM (2010) 2020 végleges]

GöPEL, Maja (2016): The Great Mindshift. Wuppertal Institute, Berlin, Springer Open. DOI: https:// doi.org/10.1007/978-3-319-43766-8

GyUlAi Iván (1991): Fenntartható fejlődés és fenntartható növekedés. Statisztikai Szemle, 91. évf. 8-9. sz. 797-822.

Human Development Report (2015). 2019 Work for Human Development. New York, United Nations Development Programme.

Human Development Report (2019). Beyond income, beyond averages, beyond today:

Inequalities in human development in the 21st century. New York, United Nations Development Programme.

IMD (2019): World Talent Ranking 2019. IMD Lausanne, Svájc.

Lanvin, Bruno -Monteiro, Felipe szerk. (2019): The Global TalentCompetitiveness Index. 2019. Fontainebleau, INSEAD, The Adecco Group, TATA Communications.

KSH (2019): A fenntartható fejlődés indikátorai Magyarországon, 2018. Budapest, Központi Statisztikai Hivatal.

Lutz, Wolfgang - Goujon, Anne - KC., Samir - Stonawski, Marcin - Stilianakis, Nikolaos szerk. (2018): Demographic and human capital scenarios for the 21st century. Luxembourg, European Union. DOI: https://doi.org/10.2760/41776

Maslow, Abraham H. (1943): A Theory of Human Motivation. Psychological Review, Vol. 50, No. 4. 370-396. DOI: https://doi.org/10.1037/h0054346

Nemzeti Fenntartható Fejlődési Tanács (NFFT) (2019): A Nemzeti Fenntartható Fejlődési Keretstratégia harmadik elörehaladási jelentése. 2017-2018.

Nordhaus, William D. - ToBin, James (1973): The Measurement of Economic and Social Performance. In Moss, Milton ed.: Is Growth Obsolete? New York, NBER. 509-564.

Our Common Future. World Commission on Environment and Development (1987). UN. Oxford, Oxford University Press.

Persányi Miklós (1988): Közös jövőnk: A Brundtland-jelentés. Budapest, Mezőgazdasági Kiadó.

Roseland, Mark (2000): Sustainable Community development: integrating environmental, economic and social objectives. Progress in Planning,Vol. 54, No. 2. 73-132. DOI: https://doi. org/10.1016/S0305-9006(00)00003-9

Roseland, Mark (2012): Towards Sustainable Communities. Gabriola Island, Canada, New Society Publishers. 
World Bank Group (2018): The Human Capital Project. Washington D.C. Elérhető: https://openknowledge.worldbank.org/bitstream/handle/10986/30498/33252.pdf? sequence=5\&isAllowed =y (2020. 04. 25.) DOI: https://doi.org/10.1016/S0305-9006(00)00003-9

\section{Internetes források}

The Catch Up Index. European Policies Initiative. Elérhetö: www.thecatchupindex.eu/TheCatchUpIndex/ (2020. 04. 28.)

www.weforum.org/reports/the-inclusive-development-index-2017 (2020. 04. 28.)

\section{Adatok az ábrákhoz}

Az adatok forrása az Eurostat és a KSH adatbázisa

3. ábra adatai

\begin{tabular}{|l|l|}
\hline Németország & 64 \\
\hline Ausztria & 62 \\
\hline Dánia & 52 \\
\hline EU átlag & 51 \\
\hline Csehország & 46 \\
\hline Szlovákia & 31 \\
\hline Magyarország & 29 \\
\hline Lengyelország & 22 \\
\hline
\end{tabular}

4. ábra adatai

\begin{tabular}{|l|c|c|}
\hline & Euro/fö & a GDP \%-ában \\
\hline Dánia & 1016 & 1,95 \\
\hline Ausztria & 970 & 2,22 \\
\hline Németország & 871 & 2,2 \\
\hline EU átlag & 438 & 1,41 \\
\hline Csehország & 234 & 1,2 \\
\hline Magyarország & 159 & 1,16 \\
\hline Lengyelország & 105 & 0,8 \\
\hline Szlovákia & 75 & 0,45 \\
\hline
\end{tabular}

5. ábra adatai

\begin{tabular}{|l|c|c|}
\hline & K + F / VA (\%) & K + F foglalkoztatottak / összes foglalkoztatott (\%) \\
\hline Ausztria & 14 & 10,2 \\
\hline Dánia & 7,8 & 6,9 \\
\hline Németország & 7 & 7 \\
\hline Csehország & 3,4 & 1,9 \\
\hline Szlovákia & 2,5 & 1,1 \\
\hline Magyarország & 2,2 & 1,6 \\
\hline Lengyelország & 2,2 & 1,8 \\
\hline
\end{tabular}


6. ábra adatai

\begin{tabular}{|c|c|}
\hline 2004 & 10116742 \\
\hline 2005 & 10097549 \\
\hline 2006 & 10076581 \\
\hline 2007 & 10066158 \\
\hline 2008 & 10045401 \\
\hline 2009 & 10030975 \\
\hline 2010 & 10014324 \\
\hline 2011 & 9985722 \\
\hline 2012 & 9931925 \\
\hline 2013 & 9908798 \\
\hline 2014 & 9877365 \\
\hline 2015 & 9855571 \\
\hline 2016 & 9830485 \\
\hline 2017 & 9797561 \\
\hline 2018 & 9778371 \\
\hline 2019 & 9772756 \\
\hline
\end{tabular}

7. ábra adatai

\begin{tabular}{|c|c|c|}
\hline \multirow{2}{*}{ EU } & Születés & Halálozás \\
\cline { 2 - 3 } & \multicolumn{2}{|c|}{1000 lakosra } \\
\hline 2016 & 9,5 & 12,9 \\
\hline 2017 & 9,4 & 13,5 \\
\hline 2014 & 9,3 & 12,8 \\
\hline 2015 & 9,3 & 13,4 \\
\hline 2018 & 9,2 & 13,4 \\
\hline 2012 & 9,1 & 13 \\
\hline 2010 & 9 & 13 \\
\hline 2013 & 9 & 12,8 \\
\hline 2011 & 8,8 & 12,9 \\
\hline
\end{tabular}

8. ábra adatai

\begin{tabular}{|l|r|r|r|r|r|}
\hline & $\mathbf{2 0 1 5}$ & $\mathbf{2 0 1 6}$ & $\mathbf{2 0 1 7}$ & $\mathbf{2 0 1 8}$ & $\mathbf{2 0 1 9}$ \\
\hline Magyarország & & & & & \\
\hline 1 évnél fiatalabb & 92855 & 91741 & 94858 & 94086 & 92771 \\
\hline 55 éves & 124815 & 123856 & 118230 & 110943 & 114178 \\
\hline 60 éves & 164139 & 157262 & 145292 & 128162 & 123688 \\
\hline Csehország & & & & & \\
\hline 1 évnél fiatalabb & 109943 & 110777 & 112544 & 114213 & 113866 \\
\hline 55 éves & 121007 & 122059 & 124141 & 127005 & 140963 \\
\hline 60 éves & 145000 & 143843 & 141607 & 136319 & 126732 \\
\hline
\end{tabular}


A fenntarthatóság mint emberi és társadalmi fejlődés

\begin{tabular}{|l|c|c|c|c|c|}
\hline & $\mathbf{2 0 1 5}$ & $\mathbf{2 0 1 6}$ & $\mathbf{2 0 1 7}$ & $\mathbf{2 0 1 8}$ & $\mathbf{2 0 1 9}$ \\
\hline Szlovákia & & & & & \\
\hline 1 évnél fiatalabb & 55513 & 56110 & 58277 & 58785 & 58445 \\
\hline 55 éves & 72474 & 73173 & 72982 & 70368 & 73080 \\
\hline 60 éves & 74869 & 76333 & 76559 & 74756 & 72387 \\
\hline Ausztria & & & & & \\
\hline 1 évnél fiatalabb & 80482 & 83341 & 86851 & 86460 & 84177 \\
\hline 55 éves & 125147 & 129753 & 135161 & 139006 & 142278 \\
\hline 60 éves & 100189 & 105421 & 112977 & 114995 & 117265 \\
\hline
\end{tabular}

9. ábra adatai

\begin{tabular}{|l|c|c|c|c|}
\hline \multirow{2}{*}{\multicolumn{1}{c|}{ Ország }} & \multicolumn{2}{|c|}{$\begin{array}{c}\text { Egészségben várható } \\
\text { élettartam }\end{array}$} & \multicolumn{2}{c|}{$\begin{array}{c}\text { 50 éves korban még } \\
\text { egészségben várható } \\
\text { évek }\end{array}$} \\
\cline { 2 - 5 } & Férfi & Nő & Férfi & Nő \\
\hline Csehország & 62,2 & 63,4 & 17,1 & 18,1 \\
\hline Magyarország & 60,4 & 61,8 & 15,3 & 16,8 \\
\hline Lengyelország & 60,5 & 64,3 & 16,4 & 18,6 \\
\hline Szlovákia & 55,5 & 56,6 & 11,9 & 12,5 \\
\hline
\end{tabular}

10. ábra adatai

\begin{tabular}{|l|c|c|}
\hline \multicolumn{1}{|c|}{ Ország } & 25-34 év & $\mathbf{1 8 - 6 9}$ év \\
\hline Dánia & 46,8 & 34,3 \\
\hline Lengyelország & 43,5 & 27,1 \\
\hline Ausztria & 40,5 & 30,6 \\
\hline EU átlag & 40,0 & 29,2 \\
\hline Szlovákia & 37,2 & 22,3 \\
\hline Csehország & 33,3 & 21,7 \\
\hline Németország & 32,3 & 26,2 \\
\hline Magyarország & 30,6 & 22,3 \\
\hline
\end{tabular}

11. ábra adatai

\begin{tabular}{|l|l|}
\hline \multicolumn{1}{|c|}{ Ország } & \\
\hline Lengyelország & 23,6 \\
\hline Dánia & 22,6 \\
\hline Ausztria & 22,0 \\
\hline Németország & 20,4 \\
\hline Csehország & 16,8 \\
\hline Szlovákia & 14,7 \\
\hline Magyarország & 12,1 \\
\hline
\end{tabular}


12. ábra adatai

\begin{tabular}{|l|r|}
\hline \multicolumn{1}{|c|}{ Ország } & \\
\hline Dánia & 24,8 \\
\hline Ausztria & 14,8 \\
\hline EU28 átlag & 11,2 \\
\hline Csehország & 8,2 \\
\hline Németország & 8,2 \\
\hline Magyarország & 6,0 \\
\hline Lengyelország & 4,9 \\
\hline Szlovákia & 3,6 \\
\hline
\end{tabular}

13. ábra adatai

\begin{tabular}{|l|c|}
\hline \multicolumn{1}{|c|}{ Ország } & 2016 (\%) \\
\hline Csehország & 0,7 \\
\hline Magyarország & 0,76 \\
\hline Lengyelország & 1,06 \\
\hline Szlovákia & 0,83 \\
\hline Ausztria & 1,79 \\
\hline Németország & 1,25 \\
\hline
\end{tabular}

14. ábra adatai

\begin{tabular}{|l|c|c|c|c|c|c|}
\hline \multicolumn{1}{|c|}{ Ország } & $\mathbf{2 0 1 4}$ & $\mathbf{2 0 1 5}$ & $\mathbf{2 0 1 6}$ & $\mathbf{2 0 1 7}$ & $\mathbf{2 0 1 8}$ & $\mathbf{2 0 1 9}$ \\
\hline Szlovákia & 29,7 & 26,5 & 22,2 & 18,9 & 14,9 & 16,1 \\
\hline Magyarország & 20,4 & 17,3 & 12,9 & 10,7 & 10,2 & 11,0 \\
\hline Csehország & 15,9 & 12,6 & 10,5 & 7,9 & 6,7 & 5,6 \\
\hline Lengyelország & 23,9 & 20,8 & 17,7 & 15,1 & 11,7 & 10,1 \\
\hline
\end{tabular}

15. ábra adatai

\begin{tabular}{|l|c|}
\hline \multicolumn{1}{|c|}{ Ország } & $\mathbf{2 0 1 7}$ \\
\hline Dánia & 50800 \\
\hline Ausztria & 42100 \\
\hline Németország & 39600 \\
\hline EU átlag & 30000 \\
\hline Csehország & 18100 \\
\hline Szlovákia & 15600 \\
\hline Magyarország & 12700 \\
\hline Lengyelország & 12200 \\
\hline
\end{tabular}


A fenntarthatóság mint emberi és társadalmi fejlődés

16. ábra adatai

\begin{tabular}{|l|r|}
\hline \multicolumn{1}{|c|}{ Ország/Régió } & $\mathbf{2 0 1 7}$ \\
\hline Dánia & 128 \\
\hline Ausztria & 127 \\
\hline Németország & 124 \\
\hline Csehország & 89 \\
\hline Szlovákia & 76 \\
\hline Lengyelország & 70 \\
\hline Magyarország & 68 \\
\hline Budapest & 139 \\
\hline Nyugat-Dunántúl & 72 \\
\hline Kelet-Dunántúl & 63 \\
\hline Pest megye & 53 \\
\hline Dél-Alföld & 48 \\
\hline Észak-Magyarország & 46 \\
\hline Dél-Dunántúl & 45 \\
\hline Észak-Alföld & 43 \\
\hline
\end{tabular}

17. ábra adatai

\begin{tabular}{|l|r|}
\hline \multicolumn{1}{|c|}{ Ország/Régió } & $\mathbf{2 0 1 6}$ \\
\hline Ausztria & 23000 \\
\hline Németország & 22000 \\
\hline Dánia & 22000 \\
\hline Csehország & 8200 \\
\hline Szlovákia & 8200 \\
\hline Lengyelország & 6500 \\
\hline Magyarország & 6000 \\
\hline
\end{tabular}

